Review

\title{
Epstein-Barr Virus in Systemic Lupus Erythematosus, Rheumatoid Arthritis and Multiple Sclerosis-Association and Causation
}

\author{
Andreas Lossius ${ }^{1}{ }^{*}$, Jorunn N. Johansen ${ }^{1}$, Øivind Torkildsen ${ }^{2}$, Frode Vartdal ${ }^{1,4}$ and \\ Trygve Holmøy ${ }^{3,4}$
}

1 Institute of Immunology, Oslo University Hospital Rikshospitalet, Oslo, Norway

2 Norwegian Multiple Sclerosis Competence Centre, Department of Neurology, Haukeland University Hospital, Bergen, Norway

3 Department of Neurology, Akershus University Hospital, Lørenskog, Norway

4 Faculty of Medicine, University of Oslo, Oslo, Norway

* Author to whom correspondence should be addressed; E-Mail: andreas.lossius@ @r-research.no; Tel.: +47-2307-3814; Fax: +47-2307-3510.

Received: 31 October 2012; in revised form: 6 December 2012 / Accepted: 7 December 2012 / Published: 13 December 2012

\begin{abstract}
Epidemiological data suggest that Epstein-Barr virus (EBV) is associated with several autoimmune diseases, such as systemic lupus erythematosus, rheumatoid arthritis and multiple sclerosis. However, it is not clear whether EBV plays a role in the pathogenesis of these diseases, and if so, by which mechanisms the virus may contribute. In this review, we discuss possible viral and immunological mechanisms that might explain associations between EBV and autoimmune diseases and whether these associations represent causes or effects of inflammation and autoimmunity.
\end{abstract}

Keywords: systemic lupus erythematosus; rheumatoid arthritis; multiple sclerosis; Epstein-Barr virus; autoimmunity; B-cells; T-cells

\section{Introduction}

Autoimmune diseases are believed to result from interactions between genetic, environmental and stochastic factors. Systemic lupus erythematosus (SLE), rheumatoid arthritis (RA) and multiple 
sclerosis (MS) are associated with certain HLA genes and more weakly to several other immune related genes [1]. However, most monozygotic twins are discordant [2], which leaves a large proportion of disease risk to be explained by factors other than heritability. Several observations argue for an important role of the environment in these diseases, including the influence of disease risk by month of birth [3], differences in worldwide geographical distribution [4] and, for MS, that people migrating before early adulthood adopt the disease risk of the country to which they migrate [5].

Several infectious agents have been suggested as environmental triggers of autoimmune diseases, but follow-up of initial studies has mostly failed to show that these agents play a specific role in the disease mechanisms. In MS, the list of proposed infectious causes is long and includes microbes, such as Spherula insularis, which was detected by microscopy of the cerebrospinal fluid (CSF) [6], but later shown not to exist [7]. Other candidates, such as paramyxovirus SV5, were suspected, based on immunological observations [8], which were later shown to be non-specific [9].

Epstein-Barr virus (EBV) was suggested early as an environmental trigger of autoimmune disease and remains a main candidate. Several studies have suggested that EBV is associated with autoimmune diseases, such as SLE, RA, MS, autoimmune thyroiditis, inflammatory bowel diseases, insulindependent diabetes mellitus, Sjögren's syndrome, systemic sclerosis, myasthenia gravis and autoimmune liver diseases. A discussion of relevant mechanisms should include more than one disease. In this review, we focus on SLE, RA and MS. We first summarize evidence of association with EBV and then critically review viral and immunological mechanisms that might explain causation or merely association.

\section{Evidence of Association}

\subsection{Serological Data}

A possible association between EBV seropositivity and autoimmune diseases was first observed by coincidence in 1968 in a Brazilian population [10]. Since then, a multitude of studies have explored humoral immunity against EBV in SLE, RA and MS. North Americans of different ethnicities with SLE had an increased seroprevalence of EBV [11,12], and studies in other populations have shown an increased frequency of antibodies against EBV early antigens [13-15]. In one study, 99\% of young SLE patients were seropositive for EBV compared to $70 \%$ of age-matched controls [16].

Almost all adult MS patients are seropositive for EBV, compared to $90 \%$ of healthy adults [17]. As for SLE, the differences in seroprevalence are more pronounced in lower age groups, where the general seroprevalence is lower [18]. Further, it has been demonstrated that MS risk is very low in individuals not infected with EBV, but increases sharply after EBV infection [19]. In a recent meta-analysis, previous EBV infection was actually found to be present in $100 \%$ of MS patients in studies using two independent methods of antibody detection [20]. The authors claimed that findings of MS patients without earlier EBV infection could be due to low sensitivity in the assays used for detection of antibodies.

In SLE and MS, titers of antibodies against EBV antigens are elevated compared to healthy controls [13,21-23], and for both diseases, this elevation seems to predate the first symptoms [24-27]. Anti-EBV nuclear antigen (EBNA)-1 IgG titers may also predict conversion from clinically isolated 
syndrome (CIS) to MS [28] and be a marker of MS disease activity [29], although the latter has been questioned by a recent study [30]. One study also indicated that exacerbations in MS were associated with reactivation of latent EBV infection [31], but these results have not been replicated [32,33]. For SLE, there is some evidence that titers of IgA antibodies against viral capsid antigen (VCA) may be associated with disease flares [34]. There is also some evidence that patients with RA have elevated serum titers of antibodies against EBV antigens [15,23,35-37]. However, in contrast to SLE and MS, it does not seem to be any association between the titers of antibodies and risk of subsequent RA [38]. The EBV seroprevalence rate among RA patients has been found to be the same as in healthy subjects [36,39].

In SLE, MS and RA, the humoral immune response against EBNA-1 may also be qualitatively different compared to healthy individuals. In MS, the strongest disease association has been demonstrated to a C-terminal EBNA-1 domain comprising amino acids (aa) 385-420 [40,41]. In a recent study including nine MS-discordant monozygotic twins, this was further narrowed down to aa 401-411, revealing increased response against this epitope in affected compared to healthy co-twins [42]. Lünemann and colleagues have demonstrated that children with MS have a broader IgG response against all three domains of the EBNA-1 protein and that some of the responses against the glycine-alanine repeat domain (aa 88-323) are directed against epitopes not found in the sera of demographically matched healthy peers [43]. A broadened EBNA-1 response with specific targets within the glycine-alanine repeat domain has also been demonstrated in pediatric SLE patients [12]. Antibodies reactive against an increased number of epitopes within the C-terminal part of EBNA-1 have been found in sera from adults with SLE and RA, supporting a broadened response towards EBNA-1 [44].

In MS and RA, it is also possible to measure the concentration of EBV-specific antibodies in body fluids that are contiguous with the diseased organs and, thus, reflect local synthesis of antibodies. Early studies on synovial fluid from RA joints did not show any evidence of the local production of antibodies against EBV [45-47]. Results are conflicting regarding intrathecal production of EBV specific antibodies in MS. One study using a large-scale protein expression clone array combined with epitope mapping identified the EBV antigens EBNA-1 and BRRF2 as frequent targets of the intrathecal antibody response in MS patients [48]. The authors also demonstrated that at least in some patients, the antibodies in the major oligoclonal bands specifically bound both EBV proteins. Another study showed a moderate, but significant increase of anti-EBNA-1 and anti-VCA antibody index (AI) in the CSF of patients with early MS [49], while the cytomegalovirus (CMV) AI was not elevated. However, recently, Otto et al. have demonstrated in a cohort of MS patients with EBV AI $\geq 2$ that the intrathecal fraction of anti-EBV antibodies is low and does not differ from anti-measles antibodies [50]. This suggests that the local production of antibodies against EBV, like that against paramyxovirus SV5 [9], may be part of the polyspecific intrathecal immune response seen in this disease.

\subsection{Infectious Mononucleosis}

In developed countries, primary EBV infection may be delayed up to adolescence, in which case it presents as infectious mononucleosis (IM) in about 35\%-50\% [51]. Interestingly, a history of IM has 
been shown to be an independent risk factor for developing MS, increasing the risk about two times [52]. In contrast, this has not been demonstrated for SLE [53-55] or RA [56].

\subsection{Cellular Immunity}

Evidence of an aberrant T-cell response against EBV has been reported in SLE, RA and MS. An early study in SLE demonstrated that T-cells were unable to control the production of immunoglobulins (Ig) from EBV-infected B-cells [57]. Later studies have reported a functionally impaired EBV specific CD8+ T-cell response characterized by the decreased production of cytokines (interferon (IFN) $-\gamma$, tumor necrosis factor (TNF)- $\alpha$, interleukin (IL)-2 and macrophage inflammatory protein-1 $\beta$ ) and decreased cytotoxicity in SLE patients [58,59], which was not seen for CMV-specific CD8+ T-cells [59]. However, the frequencies of EBV specific CD8+ T-cells have in some studies been shown to be the same in SLE patients as in healthy individuals [58,60] and, in one study, slightly increased [59]. The frequency of IFN- $\gamma$ secreting EBV-specific CD4+ T-cells has been reported to be increased [60].

The data are more conflicting in RA and MS. Early studies in RA suggested an impaired EBV specific T-cell response in blood. Thus, lymphocytes from RA patients underwent spontaneous transformation more rapidly and frequently than lymphocytes from healthy individuals [61], and T-cells were unable to control antibody production of EBV-infected B-cells [62]. Further, the frequency of EBV gp110-specific T-cells was shown to be lower in patients with RA [63]. Using A2/GLC or B8/RAK tetramers, another study demonstrated similar CD8+ T-cell frequencies against these lytic and immunodominant EBV epitopes in RA patients and healthy controls. In patients with RA, however, a lower fraction of these CD8+ T-cells produced IFN- $\gamma$ in response to their peptide antigens [64]. In contrast, a more recent study has reported an increased frequency of CD8+ T-cells responding upon stimulation with pooled lytic and latent EBV antigens [37].

Also in MS, early in vitro studies suggested an impaired CD8+ T-cell control of EBV infected B-cells $[65,66]$. Supporting this, Pender and colleagues found lower frequencies of CD8+ T-cells reacting upon in vitro stimulation with EBV lymphoblastoid cell lines (EBV-LCL) [67]. However, still more studies have demonstrated increased EBV specific CD8+ T-cell responses in MS. Cepok and colleagues found an increased frequency of EBV-LCL reactive CD8+ T-cells in blood of MS patients compared to healthy donors [48], while Hollsberg and colleagues demonstrated an increased frequency of CD8+ T-cells responding to a lytic and a latent EBV epitope in blood of MS patients compared to healthy controls [68]. Finally, a large study including 91 individuals with demyelinating disease, demonstrated an increased frequency in blood of CD8+ T-cells responding to a peptide pool comprising 18 HLA class I restricted peptides of several lytic and latent proteins, compared to 28 patients with other neurological diseases and 20 healthy controls [69]. This study also demonstrated that the CD8+ T-cell response was inversely proportional to disease duration. Thus, patients with CIS displayed higher frequencies of EBV specific T-cells than patients with established MS, and this frequency decreased in 12 out of 13 CIS patients followed prospectively for one year [69]. This temporal evolution of the EBV specific CD8+ T-cell response in MS and CIS could possibly explain the discrepancies between the latter studies and the findings of Pender and colleagues [67]. 
The CD4+ T-cell response against the latent cycle antigen EBNA-1 has been shown to be selectively increased and exhibit a broadened specificity in patients with MS [70].

As for antibodies, it is also possible to study T-cells from body fluids contiguous with the diseased organs in RA and MS. EBV specific CD8+ T-cells were shown early to be enriched in the synovial fluid compared to blood in patients with RA [71,72]. However, subsequent studies revealed that EBV specific CD8+ T-cells and, in several cases, also CMV-specific CD8+ T-cells could be locally enriched in other chronic inflammatory joint disorders (Reiter's syndrome, psoriatic arthritis, ankylosing spondylitis, osteoarthritis) and in a few patients with inflammatory processes affecting other organs (uveitis, encephalitis and MS) [73,74]. In contrast, another study showed that EBV-specific, but not CMV-specific, CD8+ T-cells were enriched in the CSF of patients with MS [49]. No such accumulation was observed in CSF from patients with other neuroinflammatory disorders [49]. We have found that CD4+ T-cells from the CSF of MS patients respond vigorously upon stimulation with EBV-transformed B-cells [75] and were later able to clone EBV DNA polymerase and EBNA-1 specific CD4+ T-cells from this compartment [76,77]. It is, however, not known whether the frequency of EBV-specific CD4+ T-cells differs between CSF and blood or in CSF between MS patients and controls.

\subsection{EBV Viral Load and Expression of Viral Genes in Blood}

SLE patients have on average a five-to-40-fold increased EBV genome load in blood compared to healthy individuals [59,60,78,79], and this is shown to be due to an increase in latently infected memory B-cells [80]. This increase seems to be independent of treatment with immunosuppressive agents $[60,78,80]$. The number of infected B-cells correlates with disease activity [80], and the viral load peaks after initiation of disease flares [59]. Patients with SLE also have an aberrant expression of the lytic gene BamHI Z leftward open reading frame-1 (BZLF-1) and the latent membrane protein (LMP)-1 and -2 genes in blood [80]. One study found that EBV viral loads correlated inversely with the frequency of EBV-specific CD4+ T-cells and positively with the frequency of EBV-specific CD8+ T-cells [60], but another study failed to replicate this [59].

Likewise, patients with RA have increased EBV DNA load in peripheral blood mononuclear cells (PBMC) [37,81-83]. The viral load was found to be the same in patients receiving or not receiving immunosuppressive treatment [83] and did not increase further after long-term treatment with methotrexate or TNF- $\alpha$ inhibitors [84]. Lünemann and colleagues have demonstrated in patients with RA that the number of EBV-specific CD8+ T-cells correlates positively with the viral load, whereas CD4+ T-cell responses against EBV and CD8+ T-cell responses to CMV antigens do not [37].

Conflicting results have been reported regarding EBV viral load in the blood of MS patients. Several studies have failed to show any difference in quantity of EBV nucleic acids between blood from patients and controls $[70,85,86]$. In contrast, one study has demonstrated an increased EBV DNA load in the PBMC of patients with CIS compared to healthy EBV carriers [28]. Others have found an increased incidence of EBV DNA in serum during exacerbations compared to stable disease periods [31]. Finally, a study has shown that the presence of plasma EBV DNA is associated with increased risk of MS [87]. 


\subsection{Detection of Virus in Diseased Organs}

RA joints and MS brains have been scrutinized for evidence of EBV infection for decades. In both diseases, conflicting results have been reported. Early studies on RA synovial membranes failed to detect EBV using indirect immunofluorescence [88] or hybridization with DNA probes for several viral genes [89]. Later studies using in situ hybridization searching for EBV encoded RNAs (EBERs) or BamH1 H leftward open reading frame-1 either failed to detect these in synovial membranes [90] or could identify EBERs in 8 to $62 \%$ of the cases [82,91-93]. However, only one study included a control virus [94]. Notably, in this study, EBV was detected in $16.7 \%$ and CMV in $20.7 \%$ of cases. Other groups have used PCR on synovial membranes or synovial fluid, with EBV positive cases ranging from $6 \%$ to $47 \%$ [82,92,95-97]. However, one study has also reported EBV in synovial lymphocytes in $33 \%$ of patients with reactive arthritis [95].

Studies using in situ hybridization for viral RNA failed to detect any EBV transcripts in MS brains $[98,99]$. However, a later study detected EBV-infected B-cells and plasma cells in brains from 21 of 22 MS cases by in situ hybridization for EBERs and immunohistochemistry for LMP-1 and LMP-2A [100]. EBV infected B-cells were mainly found in follicle-like structures in the meninges and in active brain lesions. However, this study did not include a control virus, and the authors were not able to detect EBV DNA in the CSF of MS patients with real time PCR. Several other groups have not been able to confirm the presence of EBV in the CNS of MS patients. In these negative studies, various methods, including in situ hybridization for EBERs [101-103], immunohistochemistry [101-104] or PCR for EBV RNA [101,102,104,105] or EBV DNA [101,102,105], have been used. Part of the reason for these discrepant results could be that the number of B-cell infiltrates differed between the different studies [106]. However, several groups have also studied tissue from some of the tissue blocks used in the positive study [100], without detecting EBV infected cells [101,102]. Recently, one study replicated the findings of EBER+ B-cells in active MS lesions [107]. The authors did, however, also find evidence of EBER+ cells in two of two studied cases of stroke, suggesting that the phenomenon may not be MS-specific. The associations between EBV and SLE, RA and MS are summarized in Table 1.

Table 1. Summary of associations between EBV and SLE, RA and MS.

\begin{tabular}{lcccl}
\hline & SLE & RA & MS & References \\
\hline Increased EBV seroprevalence & + & - & + & {$[11-20],[36],[39]$} \\
Elevated serum titers of anti-EBV antibodies & + & + & + & {$[14],[15],[21-27],[35-37]$} \\
Elevation of antibodies predates symptoms & + & - & + & {$[24-27],[38]$} \\
Association with infectious mononucleosis & - & - & + & {$[52-56]$} \\
Aberrant systemic T-cell response against EBV & + & + & + & {$[37],[48],[57-70]$} \\
Increased local T-cell response against EBV & N/A & + & + & {$[49],[71-74]$} \\
Increased EBV viral load in blood & + & + & $+/-$ & {$[28],[31],[37],[58],[60],[70],[78-83],[85-87]$} \\
Virus detected in diseased organ & N/A & +- & $+/-$ & {$[81],[88-105],[107]$} \\
\hline
\end{tabular}




\section{Viral mechanisms}

\subsection{Infection and Immortalization of Autoreactive B-cells}

EBV infects B-cells through binding to the viral envelope glycoprotein 350 to the B-cell complement receptor 2, CD21 [108,109]. Infection of naive B-cells leads initially to the expression of nine virally encoded proteins (EBNA 1-6 and three LMPs), and this expression pattern is referred to as the latency III program [108]. Infected cells enter the germinal center (GC) in the tonsil and change their viral transcription program to express only EBNA-1, LMP-1 and LMP-2 (latency II). It is demonstrated in vitro that LMP-1 serves a signal that normally comes from the CD40 signal transduction pathway initiated by CD4+ T-cells [110,111], whereas LMP-2A mimics a constitutively activated B-cell receptor [112]. LMP-1 and LMP-2A assist infected naive B-cells in the GC process and help EBV to gain access to the memory B-cell pool, where it enters a truly latent state (latency $0 / \mathrm{I})$.

It has been hypothesized that EBV might infect autoreactive naive B-cells, and drive these into latently infected memory B-cells resistant to apoptosis. These cells could then lodge in the organs, where their target antigens are expressed and act as antigen presenting cells (APC) rescuing autoreactive T-cells [113,114]. Based on in vitro studies, it was previously thought that LMP-1 and LMP-2A were sufficient to drive infected B-cells through the GC even in the absence of antigen [108] and that this mechanism could allow the escape of autoreactive B-cells. Indeed, in transgenic mouse models, LMP-2A expression in B-cells prevented induction of energy in autoreactive B-cells [115] and led to the bypass of tolerance checkpoints, resulting in high serum levels of autoantibodies and to the development of lupus-like disease [116]. However, a more recent in vivo study showed that EBV infected GC B-cells, while expressing LMP-1 and LMP-2A, retained both phenotypic and functional characteristics of normal GC B-cells [117]. The authors suggested a more modest role for these EBV latency II proteins, perhaps only supplementing physiological signals. In line with this idea, Tracy and colleagues did not find any evidence that EBV favored the survival of autoreactive B-cells during IM [118]. On the contrary, EBV infected memory B-cells were found to express lower levels of self- and poly-reactive antibodies than their uninfected counterparts. Further, antibodies made by EBV positive and EBV negative B-cell populations showed no difference in the distribution of isotypes, $\mathrm{VH}$ and $\mathrm{JH}$ usage, the extent of somatic hypermutations or CDR3 length.

\subsection{EBV Infection of Other Cell Populations}

In addition to B-cells, EBV may also target other cells in vivo, including T-cells $[119,120]$ and NK cells [121]. It has been proposed that infection of T-cells could impair T-cell apoptosis through inactivation of NF- $\mathrm{KB}$ by the expression of the EBV ZEBRA protein [122] and enhanced p53 signaling [123]. Apoptosis of autoreactive T-cells is believed to be fundamental for the maintenance of self-tolerance, but it remains to be established whether EBV-mediated impairment through the proposed mechanism is relevant in the pathogenesis of autoimmune diseases.

EBV infection of human astrocytes and brain microvascular endothelial cell lines has been demonstrated in vitro [124,125]. It has been proposed that reactivation of latent EBV infection in brain 
endothelial cells could up-regulate cytokines, chemokines and adhesion molecules that could facilitate access of lymphocytes to the brain [125]. The relevance of this hypothesis, which rests on the unproven assumption that EBV infects human endothelial cells in vivo, remains to be shown. Notably, evidence of the latent or active EBV infection of endothelial cells has so far not been reported in MS brains [98-105,107].

\subsection{Innate Immunity}

It has been postulated that EBV could exacerbate inflammation in autoimmune diseases by enhancing innate immune responses [126]. Thus, LMP-1 has been shown in vitro to prime production of IFN- $\alpha$ in EBV-infected B-cells [127] and to upregulate the expression of the B-cell activating factor of the tumor necrosis family (BAFF) [110], IL-6 [128] and IL-10 [129].

Serum levels of IFN- $\alpha$ are increased in SLE and correlate with disease activity [130]. The mechanism behind this probably involves both Toll-like receptor (TLR)-dependent and independent mechanisms [131]. Plasmacytoid dendritic cells from healthy individuals have been shown to produce large amounts of IFN- $\alpha$ when cultured in the presence of EBV DNA and RNA, through a mechanism involving engagement of TLR-9 and -7 [132]. Others have found that LMP-1 and IFN- $\alpha$ are co-expressed in PBMC from SLE patients [133]. The authors of this study suggest that TLR-7-stimulation of EBV infected B-cells may induce LMP-1-mediated secretion of IFNs and, thereby, drive a vicious cycle, leading to enhanced antibody production and tissue damage.

In MS, Tzartos and colleagues detected overexpression of EBERs and IFN- $\alpha$ in active areas of white matter lesions, whereas neither IFN- $\alpha$ nor EBERs were expressed in inactive lesions [107]. The authors also demonstrated in vitro that EBERs are able to elicit IFN- $\alpha$ production in TLR-3-expressing HEK cells and suggested that EBV could drive inflammation through activation of innate immune responses. Serafini and colleagues observed a strong expression of BAFF in the cytoplasm of EBV infected B-cells in acute MS lesions and ectopic B-cell follicles, and they proposed that EBV activation signals might be amplified by the autocrine and paracrine actions of BAFF [134].

\subsection{The State of EBV Infected B-cells in a Chronically Inflamed Environment}

While EBV infection and reactivation possibly could trigger inflammation, it is also conceivable that the proinflammatory environment in autoimmune diseases may alter the regulation of EBV latency, leading to reactivation of the virus. Supporting this idea, it has been demonstrated in vitro that several cytokines, including IFN- $\alpha$ [135], IL-10 [136] and IL-21 [137], induce LMP-1 expression in EBV infected B-cells. Notably, it has been shown that the expression of these cytokines are increased in diseased organs of patients with MS [107,138,139] and RA [140-143] and in the blood of patients with SLE [130,144,145]. Moreover, cross-linking of the B-cell receptor of EBV infected B-cells activates transcription of BZLF-1, resulting in lytic EBV replication [146]. Likewise, activation of B-cells resulting in terminal differentiation into plasma cells seems to initiate the replicative EBV cycle in vivo [147]. Such mechanisms could potentially explain i) higher EBV viral loads in serum of patients with SLE and RA, ii) increased expression of LMP-1 and BZLF-1 in the blood of patients with SLE, iii) a possible detection of EBV in the inflamed organs of RA and MS and iv) a secondary increased humoral and cellular response against EBV (as detailed in sections 2.4, 2.5, 2.1 and 2.3). 
There is a significant accumulation of memory B-cells in or near the diseased organs of patients with RA [148] and MS [149,150]. As EBV resides in latently infected memory B-cells, such accumulations increase the probability that EBV will be present and exposed to the local inflammatory environment. Ectopic lymphocyte aggregates and B-cell follicles have been detected in some patients with long-standing MS [151,152] and would be expected to harbor some EBV infected B-cells. They have indeed been reported to be major sites of EBV persistence [100], but this finding has so far not been replicated (detailed in section 2.5).

\subsection{Transactivation of Human Endogenous Retroviruses}

Human endogenous retroviruses (HERVs) have been proposed to link infection and autoimmunity [153]. Hence, EBV induces transcription of the endogenous retrovirus HERV-K18, which encodes a superantigen that activates the T-cells carrying the T-cell receptor (TCR) V $\beta 7$ and V $\beta 13$ families [154]. The expression of HERV-K18 has been shown to be elevated in peripheral blood and inflamed joints of patients with juvenile RA, but not in the peripheral blood of pediatric patients with SLE [155]. One of the three HERV-K18 Env alleles (K18.3) was reported to be associated with MS in a case-control study, although the replication analysis in an independent sample set was non-significant [156]. Interestingly, human herpesvirus-6A may also be associated with MS [157] and is, like EBV, also shown to transactivate HERV-K18 [156]. However, there is no evidence for the selective expansion of T-cells carrying the TCR V $\beta 7$ and V $\beta 13$ families in the brain [158], blood or CSF (Lossius et al., unpublished) of MS patients, or in the synovial tissue from joints of RA patients $[159,160]$.

Recently, EBV has also been demonstrated in vitro to activate HERV-W, also known as MS-associated retrovirus (MSRV), in astrocytes, B-cells and monocytes from MS patients [161]. MSRV has repeatedly been isolated from patients with MS [162-164] and has previously been shown in vitro to stimulate T-cells carrying TCRs of the V $\beta 16$ family [165] and to induce the production of several cytokines [166-168].

\section{Immunological Mechanisms}

\subsection{Molecular Mimicry and Mistaken Self}

Molecular mimicry, first proposed by Fujinami and Oldstone [169], is one of the main hypotheses on how infections may cause autoimmunity. Sequence or structural similarities between microbial and self-antigens are believed to cause cross-reactivity of T-cells, B-cells and antibodies. It has been shown that cross-reactive antibodies are involved in the pathogenesis of Sydenham chorea, Guillain-Barré syndrome and HTLV-1 associated myelopathy. In contrast, although there is strong circumstantial evidence [170,171] and the mechanism is shown to be relevant in animal models of autoimmune diseases [172], cross-reactive T-cells have so far not been shown to mediate human disease.

In SLE, autoantibodies against epitopes on $\mathrm{SmB}^{\prime}$ and $\mathrm{SmD} 1$ have been shown to cross-react with different domains of EBNA-1 [173,174]. Rabbits immunized with the EBNA-1 motif PPPGRRP acquired lupus-like autoimmune disease [175]. Immunization of mice with the entire EBNA-1 protein led to the development of anti-dsDNA and anti-Sm antibodies [176]. Furthermore, antibodies against 
Ro (aa 169-180), the earliest detectable autoantibodies in a subgroup of SLE patients, have been shown to cross-react with EBNA-1 (aa 58-72). Immunization of rabbits with either peptide induced a humoral immune response against both antigens, with the subsequent epitope spreading to other antigenic determinants of Ro and to other lupus associated autoantigens. The rabbits eventually developed SLE-like symptoms, such as leukopenia, thrombocytopenia and renal dysfunction [177].

Anti-citrullinated protein antibodies (ACPA) are present in the sera of most patients with RA. These post-translational modified proteins are products of peptidyl arginine deiminase (PAD), the enzyme catalyzing the conversion of arginine residues into citrulline [178]. In the inflamed synovium, dying cells might leak PAD, which could become activated by the high extracellular calcium concentration. Alternatively, the enzyme could be activated through calcium influx in apoptotic cells. In such settings, EBV proteins may become substrates for post-translational citrullination and, thereby, possible targets for ACPA. Supporting this idea, a study detected antibodies specific for a citrullinated EBNA-1 peptide (aa 35-58) in approximately 50\% of RA sera and in less than 5\% of normal and disease control sera, and the authors speculated whether EBV infection may play a role in the induction of ACPA [179].

HLA molecules carrying the amino acid sequence QKRAA, QRRAA or RRRAA at positions 70-74 of the DR $\beta 1$ chain are associated with ACPA positive RA [180]. The QKRAA determinant is also expressed on the EBV protein gp110 and has been shown to be a target of humoral and cellular immune responses in humans [181]. One group found reduced frequencies of T-cells responsive to gp110 in patients with RA [63]. However, others have found an increased humoral and cellular response in RA against gp110, but also against several other microorganisms that express the QKRAA motif, including Brucellaovis and Lactobacillus lactis [182].

The HLA class II allele DRB1*1501 is the strongest genetic risk factor for MS. DRB1*1501 is in strong linkage disequilibrium with DRB5*0101, and these two alleles may be involved in molecular mimicry between EBV and the myelin basic protein (MBP) in MS. Thus, Lang and colleagues demonstrated that the Hy.2E11 TCR from an MS patient cross-recognized a DRB1*1501-restricted MBP peptide and a DRB5*0101 restricted EBV DNA polymerase peptide [183]. A later study, which used humanized mice carrying DRB $1^{*} 1501$ and DRB5*0101, as well as the cross-reactive Hy.2E11 TCR, suggested a functional epistasis between DRB1*1501 and DRB5*0101 [184]. Thus, DRB5*0101 ameliorated experimental autoimmune encephalomyelitis in mice also carrying DRB1*1501. The relevance of these observations for MS remains to be proven. We have found, however, that CD4+ T-cells cross-recognizing these particular MBP and EBV epitopes were prevalent in the CSF of an MS patient [75]. Others have shown that MS patients have clonal expansions of EBNA-1 specific T-cells in blood that recognize myelin antigens more frequently than other tested autoantigens [185]. These cross-reactive T-cells co-produced IFN- $\gamma$ and IL-2, which is a characteristic of polyfunctional T-cells.

The small heat shock protein $\alpha \mathrm{B}$-crystallin is expressed in MS lesions, but not in normal white matter and has been identified as a candidate autoantigen in MS [186]. Human B-cells do not usually express $\alpha \mathrm{B}$-crystallin, but do so upon EBV infection in which case they also may present $\alpha \mathrm{B}$-crystallin peptides on their HLA class II alleles molecules to $\alpha B$-crystallin specific T-cells [187]. This gave rise to the "mistaken self hypothesis" [188], suggesting that peripheral EBV infection of lymphoid cells prime the human $\mathrm{T}$-cell repertoire not only to microbial antigens, but also to de novo expressed 
$\alpha \mathrm{B}$-crystallin in infected lymphoid cells. Further studies in transgenic mice have shown that $\alpha B$-crystallin is a negative regulator of inflammation and apoptosis in the CNS [189]. Sequence similarities have been found in silico between $\alpha$ B-crystallin and EBNA-1 (aa 385-420) [190]. The levels of antibodies specific for this part of EBNA-1, the presence of HLA DRB1*15 and the absence of HLA A*02 have been shown to be interacting risk factors in MS, supporting a role for this EBNA-1 domain in the immunopathogenesis [40,41].

\subsection{Bystander Activation and Epitope Spreading}

Another theory on how infections may induce or augment autoimmunity is referred to as bystander activation. In this scenario, the inflammatory setting of an infection promotes activation of or expansion of previously activated, autoreactive lymphocytes [191-193]. Bystander activation may be antigen-independent, when autoreactive lymphocytes are stimulated by cytokines or superantigens, or antigen-dependent in the setting of tissue destruction and presentation of self-antigens by APC to autoreactive T- or B-cells [192]. The latter mechanism may be amplified by further tissue damage and presentation of additional self-antigens, resulting in activation of lymphocytes of other specificities. This process is known as epitope spreading and might involve new epitopes on the same [194] or on different molecules [195]. B-cell epitope spreading has been shown to take place in rabbits acquiring lupus-like disease after immunization with an EBNA-1 peptide (detailed in section 4.1) [177]. A possible broadened humoral response against EBNA-1 in MS [43], SLE [12,44] and RA [44] and the broadened T-cell response against this antigen in MS [70] might be a result of intramolecular epitope spreading.

One might speculate whether the severe systemic inflammation during IM may promote bystander activation and expansion of autoreactive lymphocytes, potentially explaining the association with MS. However, it remains to be proven whether such a mechanism could be relevant. Notably, a recent study found evidence of activation, but not expansion, of the influenza and CMV-specific memory T-cell pools during IM [196].

Bar-Or and colleagues have proposed that abnormal B-cell cytokine responses in patients with MS might mediate bystander activation of disease-relevant T-cells, resulting in increased disease activity [197]. Supporting this in MS, they demonstrated that depletion of B-cells in vivo and ex vivo reduced inflammatory CD4+ and CD8+ T-cell responses [197]. Soluble products from B-cells of untreated MS patients reconstituted the diminished T-cell responses, an effect that seemed to be partly mediated by lymphotoxin and TNF- $\alpha$.

\subsection{Dual and Chimeric TCRs}

An $\alpha \beta$ T-cell carries a TCR consisting of an $\alpha$ and $\beta$ chain, in which the variable regions are products of V-J and V-D-J gene recombinations, respectively. However, studies in humans have revealed that about $30 \%$ of $\alpha \beta$ T-cells express functional dual V $\alpha$ TCRs and $1 \%$ expresses dual $\mathrm{V} \beta$ TCRs. In addition, there are some T-cells expressing different chimeric TCRs generated by a single $\mathrm{V} \alpha$ or $\mathrm{V} \beta$ combining with two different $\mathrm{V} \beta$ or $\mathrm{V} \alpha$, respectively. A potential mechanism giving rise to autoimmunity could be that two different TCRs allow autoreactive T-cells to escape the negative selection mechanisms in the thymus [198]. It has recently been demonstrated that a viral infection in 
mice could trigger CNS autoimmunity by activating T-cells expressing different TCRs specific for viral and myelin antigens [199]. Such a mechanism has, however, so far not been linked to EBV.

\subsection{Polyspecific B-cell Activation}

There are some indications that raised serum titers of antibodies against EBV in autoimmune diseases could be caused by polyspecific B-cell activation. Memory B-cells have been shown to proliferate and differentiate into plasma cells in response to polyclonal stimuli, and this could represent a natural mechanism for the maintenance of lifelong serological immunity [200]. Such stimuli include bystander T-cell help through CD40L and bacterial CpG DNA stimulation of TLRs [200]. Notably, both these mechanisms have been shown to be dysregulated in autoimmune diseases [201-206]. Indeed, SLE is associated with hypergammaglobulinemia, and one recent study demonstrated elevated titers of antibodies against several microbes, including EBV [13]. Besides MS, intrathecal oligoclonal bands may also be found in several infectious diseases of the central nervous system, in which case the IgG bands are directed against the etiological agent [207,208]. In MS, there is an intrathecal synthesis of antibodies against several viruses [209], but these antibodies are not part of the major oligoclonal CSF IgG bands [210]. The intrathecal immune response against EBNA-1 in MS may be a part of this local polyspecific humoral response [50]. Supporting this, recombinant antibodies made from single sorted expanded plasma cells in the CSF of a patient with subacute sclerosing panencephalitis were specific for measles virus [211], the causative pathogen, whereas recombinant CSF antibodies from MS patients did not react with EBV [105]. The serum and CSF measles antibody levels in MS have been found to increase over time [212], further supporting the idea of a polyspecific humoral response. Moreover, one prospective study has found that elevated serum titers of IgG not only against EBNA-1, but also against herpesvirus-6 were associated with increased risk of MS [213]. A recent study demonstrated distinct profiles of antibodies against herpes viruses in neuromyelitis optica and MS [214]. As previously found, MS patients had elevated levels of antibodies against EBNA-1, but they also showed elevated levels of antibodies against varicella zoster virus compared to the NMO patients.

\subsection{Accumulation of EBV-specific CD8+ T-cells in Sites of Inflammation}

As detailed in section 2.3, EBV specific CD8+ T-cells are enriched in or near the diseased organs of patients with RA [71,72] and MS [49]. This could reflect a local immune response against EBV in the diseased organs, but other explanations have also been suggested. EBV-specific CD8+ T-cells have also been reported to accumulate in synovial fluid from patients with psoriatic arthritis, osteoarthritis and Reiter's syndrome [73,74], indicating an unspecific "trapping" of virus-specific T-cells within inflamed sites. In such a scenario, frequent reactivations of the virus in the periphery activate new T-cells, which favor homing to inflamed tissues, due to increased sensitivity to chemotactic factors [73]. In line with this idea, acute lymphocytic choriomeningitis virus infection in mice harboring mycobacterium-induced granulomas led to substantial accumulation of virus-specific T-cells in the inflamed granulomas [215]. 


\section{Conclusions}

After decades of epidemiological, viral and immunological research, it is still an open question whether the observed association between EBV and autoimmunity represent causation. It is striking that for SLE, RA and MS, most associations with EBV are valid for more than one disease. For instance, both SLE and MS are associated with an increased seroprevalence of EBV; all diseases are associated with elevated serum titers of anti-EBV antibodies and a perturbed T-cell response against the virus. It seems likely that at least some of these shared associations reflect shared mechanisms. Such mechanisms could possibly involve B-cells, which are central players in the pathogenesis of SLE [216], RA [217] and MS [218] and also the main site of EBV persistence [219].

Basic research on possible mechanisms is hampered by the fact that EBV does not infect animals commonly used in models of autoimmune diseases. Several research groups have developed humanized mouse models of EBV infection [220,221], and a recent study demonstrated erosive arthritis resembling RA in the majority of such mice [222]. However, the mouse models are based upon transfer of human hematopoietic stem cells and are complicated with graft versus host disease [223], which is a major confounder when studying autoimmunity.

Future research should continue to investigate hypotheses on EBV as a causative risk factor in autoimmunity. Conversely, it is equally important to explore whether the associations with EBV could merely represent the effects of autoimmune inflammation. One important task in MS is to identify the mechanisms driving the increase in serum titers of anti-EBNA-1 antibodies prior to the onset of symptoms, as these may represent pathogenic events [27]. EBV vaccination programs could possibly give reliable, although late, answers to the question of cause and effect. On one hand, vaccination studies may not be justified for autoimmune diseases, given their rarity, the lack of definitive proof of causality, the possible risk of eliciting harmful immune responses against the vaccine and the risk of postponing primary infection to a more vulnerable age. On the other hand, vaccination might also prevent EBV-associated malignancies and IM, which in some cases shows a protracted course and even lead to serious complications in about $1 \%$ of the cases [224]. It is, of course, a prerequisite to develop efficient vaccines with a proven safety profile. To date, several vaccines are under development [224], one of which has shown some efficacy in a phase II trial in preventing infectious mononucleosis, but not in preventing asymptomatic infection [225].

\section{Conflict of Interest}

The authors declare no conflict of interest.

\section{References}

1. Lessard, C.J.; Ice, J.A.; Adrianto, I.; Wiley, G.B.; Kelly, J.A.; Gaffney, P.M.; Montgomery, C.G.; Moser, K.L. The genomics of autoimmune disease in the era of genome-wide association studies and beyond. Autoimmunity reviews 2012, 11, 267-275.

2. Bogdanos, D.P.; Smyk, D.S.; Rigopoulou, E.I.; Mytilinaiou, M.G.; Heneghan, M.A.; Selmi, C.; Gershwin, M.E. Twin studies in autoimmune disease: genetics, gender and environment. Journal of Autoimmunity 2012, 38, 156-169. 
3. Disanto, G.; Chaplin, G.; Morahan, J.M.; Giovannoni, G.; Hypponen, E.; Ebers, G.C.; Ramagopalan, S.V. Month of birth, vitamin D and risk of immune mediated disease: A case control study. BMC medicine 2012, 10, 69.

4. Moroni, L.; Bianchi, I.; Lleo, A. Geoepidemiology, gender and autoimmune disease. Autoimmunity reviews 2012, 11, 386-392.

5. Handel, A.E.; Giovannoni, G.; Ebers, G.C.; Ramagopalan, S.V. Environmental factors and their timing in adult-onset multiple sclerosis. Nature reviews. Neurology 2010, 6, 156-166.

6. Chevassut, K. Aetiology of disseminated sclerosis. Lancet 1930, 215, 552-560.

7. Howard-Jones, N. Fake! Br. Med. J. (Clin. Res. Ed.) 1982, 284, 511.

8. Goswami, K.K.; Randall, R.E.; Lange, L.S.; Russell, W.C. Antibodies against the paramyxovirus SV5 in the cerebrospinal fluids of some multiple sclerosis patients. Nature 1987, 327, 244-247.

9. Vandvik, B.; Norrby, E., Paramyxovirus SV5 and multiple sclerosis. Nature 1989, 338, 769-771.

10. Dalldorf, G.; Carvalho, R.P.; Jamra, M.; Frost, P.; Erlich, D.; Marigo, C. The lymphomas of Brazilian children. JAMA : the Journal of the American Medical Association 1969, 208, 1365-1368.

11. James, J.A.; Neas, B.R.; Moser, K.L.; Hall, T.; Bruner, G.R.; Sestak, A.L.; Harley, J.B. Systemic lupus erythematosus in adults is associated with previous Epstein-Barr virus exposure. Arthritis and Rheumatism 2001, 44, 1122-1126.

12. McClain, M.T.; Poole, B.D.; Bruner, B.F.; Kaufman, K.M.; Harley, J.B.; James, J.A. An altered immune response to Epstein-Barr nuclear antigen 1 in pediatric systemic lupus erythematosus. Arthritis and Rheumatism 2006, 54, 360-368.

13. Berkun, Y.; Zandman-Goddard, G.; Barzilai, O.; Boaz, M.; Sherer, Y.; Larida, B.; Blank, M.; Anaya, J.M.; Shoenfeld, Y. Infectious antibodies in systemic lupus erythematosus patients. Lupus 2009, 18, 1129-1135.

14. Esen, B.A.; Yilmaz, G.; Uzun, S.; Ozdamar, M.; Aksozek, A.; Kamali, S.; Turkoglu, S.; Gul, A.; Ocal, L.; Aral, O.; et al. Serologic response to Epstein-Barr virus antigens in patients with systemic lupus erythematosus: A controlled study. Rheumatology International 2012, 32, 79-83.

15. Draborg, A.; Jorgensen, J.; Muller, H.; Nielsen, C.; Jacobsen, S.; Iversen, L.; Theander, E.; Nielsen, L.; Houen, G.; Duus, K. Epstein-Barr virus early antigen diffuse (EBV-EA/D)-directed immunoglobulin A antibodies in systemic lupus erythematosus patients. Scandinavian Journal of Rheumatology 2012, 41, 280-289.

16. James, J.A.; Kaufman, K.M.; Farris, A.D.; Taylor-Albert, E.; Lehman, T.J.; Harley, J.B. An increased prevalence of Epstein-Barr virus infection in young patients suggests a possible etiology for systemic lupus erythematosus. The Journal of Clinical Investigation 1997, 100, 3019-3026.

17. Ascherio, A.; Munch, M. Epstein-Barr virus and multiple sclerosis. Epidemiology 2000, $11,220-224$.

18. Alotaibi, S.; Kennedy, J.; Tellier, R.; Stephens, D.; Banwell, B. Epstein-Barr virus in pediatric multiple sclerosis. JAMA : the Journal of the American Medical Association 2004, 291, 1875-1879.

19. Levin, L.I.; Munger, K.L.; O'Reilly, E.J.; Falk, K.I.; Ascherio, A. Primary infection with the Epstein-Barr virus and risk of multiple sclerosis. Annals of Neurology 2010, 67, 824-830. 
20. Pakpoor, J.; Disanto, G.; Gerber, J.E.; Dobson, R.; Meier, U.C.; Giovannoni, G.; Ramagopalan, S.V. The risk of developing multiple sclerosis in individuals seronegative for Epstein-Barr virus: a meta-analysis. Mult. Scler. 2012, doi: 10.1177/1352458512449682.

21. Evans, A.S.; Rothfield, N.F.; Niederman, J.C. Raised antibody titres to E.B. virus in systemic lupus erythematosus. Lancet 1971, 1, 167-168.

22. Larsen, P.D.; Bloomer, L.C.; Bray, P.F. Epstein-Barr nuclear antigen and viral capsid antigen antibody titers in multiple sclerosis. Neurology 1985, 35, 435-438.

23. Shirodaria, P.V.; Haire, M.; Fleming, E.; Merrett, J.D.; Hawkins, S.A.; Roberts, S.D. Viral antibody titers. Comparison in patients with multiple sclerosis and rheumatoid arthritis. Archives of Neurology 1987, 44, 1237-1241.

24. Ascherio, A.; Munger, K.L.; Lennette, E.T.; Spiegelman, D.; Hernan, M.A.; Olek, M.J.; Hankinson, S.E.; Hunter, D.J. Epstein-Barr virus antibodies and risk of multiple sclerosis: A prospective study. JAMA: the Journal of the American Medical Association 2001, 286, 3083-3088.

25. McClain, M.T.; Bruner, T.L.; Dennis, G.J.; Harley, J.B.; James, J.A. The temporal relationship between the onset of anti-EBNA-1 and lupus autoimmunity supports a role for EBV in the development if SLE. Arthritis and Rheumatism 2003, 48, 674.

26. Heinlen, L.D.; McClain, M.T.; Dennis, G.J.; Rubertone, M.V.; Harley, J.B.; James, J.A. The development of antibodies targeting Epstein-Barr virus closely parallels autoimmune progression near the onset of SLE. Arthritis and Rheumatism 2003, 48, 662.

27. Levin, L.I.; Munger, K.L.; Rubertone, M.V.; Peck, C.A.; Lennette, E.T.; Spiegelman, D.; Ascherio, A. Temporal relationship between elevation of epstein-barr virus antibody titers and initial onset of neurological symptoms in multiple sclerosis. JAMA : the Journal of the American Medical Association 2005, 293, 2496-2500.

28. Lunemann, J.D.; Tintore, M.; Messmer, B.; Strowig, T.; Rovira, A.; Perkal, H.; Caballero, E.; Munz, C.; Montalban, X.; Comabella, M. Elevated Epstein-Barr virus-encoded nuclear antigen-1 immune responses predict conversion to multiple sclerosis. Annals of Neurology 2010, 67, 159-169.

29. Farrell, R.A.; Antony, D.; Wall, G.R.; Clark, D.A.; Fisniku, L.; Swanton, J.; Khaleeli, Z.; Schmierer, K.; Miller, D.H.; Giovannoni, G. Humoral immune response to EBV in multiple sclerosis is associated with disease activity on MRI. Neurology 2009, 73, 32-38.

30. Ingram, G.; Bugert, J.J.; Loveless, S.; Robertson, N.P. Anti-EBNA-1 IgG is not a reliable marker of multiple sclerosis clinical disease activity. European Journal of Neurology: The Official Journal of the European Federation of Neurological Societies 2010, 17, 1386-1389.

31. Wandinger, K.; Jabs, W.; Siekhaus, A.; Bubel, S.; Trillenberg, P.; Wagner, H.; Wessel, K.; Kirchner, H.; Hennig, H. Association between clinical disease activity and Epstein-Barr virus reactivation in MS. Neurology 2000, 55, 178-184.

32. Buljevac, D.; van Doornum, G.J.; Flach, H.Z.; Groen, J.; Osterhaus, A.D.; Hop, W.; van Doorn, P.A.; van der Meche, F.G.; Hintzen, R.Q. Epstein-Barr virus and disease activity in multiple sclerosis. Journal of Neurology, Neurosurgery, and Psychiatry 2005, 76, 1377-1381. 
33. Torkildsen, O.; Nyland, H.; Myrmel, H.; Myhr, K.M. Epstein-Barr virus reactivation and multiple sclerosis. European Journal of Neurology: The Official Journal of the European Federation of Neurological Societies 2008, 15, 106-108.

34. Chen, C.J.; Lin, K.H.; Lin, S.C.; Tsai, W.C.; Yen, J.H.; Chang, S.J.; Lu, S.N.; Liu, H.W. High prevalence of immunoglobulin A antibody against Epstein-Barr virus capsid antigen in adult patients with lupus with disease flare: Case control studies. The Journal of Rheumatology 2005, 32, 44-47.

35. Catalano, M.A.; Carson, D.A.; Slovin, S.F.; Richman, D.D.; Vaughan, J.H. Antibodies to Epstein-Barr virus-determined antigens in normal subjects and in patients with seropositive rheumatoid arthritis. Proceedings of the National Academy of Sciences of the United States of America 1979, 76, 5825-5828.

36. Ferrell, P.B.; Aitcheson, C.T.; Pearson, G.R.; Tan, E.M. Seroepidemiological study of relationships between Epstein-Barr virus and rheumatoid arthritis. The Journal of Clinical Investigation 1981, 67, 681-687.

37. Lunemann, J.D.; Frey, O.; Eidner, T.; Baier, M.; Roberts, S.; Sashihara, J.; Volkmer, R.; Cohen, J.I.; Hein, G.; Kamradt, T.; et al. Increased frequency of EBV-specific effector memory CD8+ T-cells correlates with higher viral load in rheumatoid arthritis. J. Immunol 2008, 181, 991-1000.

38. Goldstein, B.L.; Chibnik, L.B.; Karlson, E.W.; Costenbader, K.H., Epstein-Barr virus serologic abnormalities and risk of rheumatoid arthritis among women. Autoimmunity 2012, 45, 161-168.

39. Yazbek, M.A.; Barros-Mazon, S.; Rossi, C.L.; Londe, A.C.; Costallat, L.T.; Bertolo, M.B. Association analysis of anti-Epstein-Barr nuclear antigen-1 antibodies, anti-cyclic citrullinated peptide antibodies, the shared epitope and smoking status in Brazilian patients with rheumatoid arthritis. Clinics 2011, 66, 1401-1406.

40. Sundstrom, P.; Nystrom, M.; Ruuth, K.; Lundgren, E. Antibodies to specific EBNA-1 domains and HLA DRB1*1501 interact as risk factors for multiple sclerosis. Journal of Neuroimmunology 2009, 215, 102-107.

41. Sundqvist, E.; Sundstrom, P.; Linden, M.; Hedstrom, A.K.; Aloisi, F.; Hillert, J.; Kockum, I.; Alfredsson, L.; Olsson, T., Epstein-Barr virus and multiple sclerosis: Interaction with HLA. Genes and Immunity 2012, 13, 14-20.

42. Mechelli, R.; Anderson, J.; Vittori, D.; Coarelli, G.; Annibali, V.; Cannoni, S.; Aloisi, F.; Salvetti, M.; James, J.A.; Ristori, G. Epstein-Barr virus nuclear antigen-1 B-cell epitopes in multiple sclerosis twins. Mult. Scler. 2011, 17, 1290-1294.

43. Lunemann, J.D.; Huppke, P.; Roberts, S.; Bruck, W.; Gartner, J.; Munz, C. Broadened and elevated humoral immune response to EBNA1 in pediatric multiple sclerosis. Neurology 2008, 71, 1033-1035.

44. Petersen, J.; Rhodes, G.; Roudier, J.; Vaughan, J.H. Altered immune response to glycine-rich sequences of Epstein-Barr nuclear antigen-1 in patients with rheumatoid arthritis and systemic lupus erythematosus. Arthritis and Rheumatism 1990, 33, 993-1000.

45. Cremer, N.E.; Hurwitz, D.; Quismorio, F.P.; Lennette, E.H.; Friou, G.J. Antiviral antibodies in rheumatoid synovial fluid and cryoprecipitates. Clinical and experimental immunology 1974, 18, 27-37. 
46. Alspaugh, M.A.; Henle, G.; Lennette, E.T.; Henle, W. Elevated levels of antibodies to Epstein-Barr virus antigens in sera and synovial fluids of patients with rheumatoid arthritis. The Journal of Clinical Investigation 1981, 67, 1134-1140.

47. Musiani, M.; Zerbini, M.; Ferri, S.; Plazzi, M.; Gentilomi, G.; La Placa, M. Comparison of the immune response to Epstein-Barr virus and cytomegalovirus in sera and synovial fluids of patients with rheumatoid arthritis. Annals of the Rheumatic Diseases 1987, 46, 837-842.

48. Cepok, S.; Zhou, D.; Srivastava, R.; Nessler, S.; Stei, S.; Bussow, K.; Sommer, N.; Hemmer, B., Identification of Epstein-Barr virus proteins as putative targets of the immune response in multiple sclerosis. The Journal of Clinical Investigation 2005, 115, 1352-1360.

49. Jaquiery, E.; Jilek, S.; Schluep, M.; Meylan, P.; Lysandropoulos, A.; Pantaleo, G.; Du Pasquier, R.A. Intrathecal immune responses to EBV in early MS. European Journal of Immunology 2010, 40, 878-887.

50. Otto, C.; Oltmann, A.; Stein, A.; Frenzel, K.; Schroeter, J.; Habbel, P.; Gartner, B.; Hofmann, J.; Ruprecht, K. Intrathecal EBV antibodies are part of the polyspecific immune response in multiple sclerosis. Neurology 2011, 76, 1316-1321.

51. Cohen, J.I., Epstein-Barr virus infection. The New England Journal of Medicine 2000, 343, 481-492.

52. Handel, A.E.; Williamson, A.J.; Disanto, G.; Handunnetthi, L.; Giovannoni, G.; Ramagopalan, S.V. An updated meta-analysis of risk of multiple sclerosis following infectious mononucleosis. PloS one 2010, 5, e12496.

53. Strom, B.L.; Reidenberg, M.M.; West, S.; Snyder, E.S.; Freundlich, B.; Stolley, P.D. Shingles, allergies, family medical history, oral contraceptives, and other potential risk factors for systemic lupus erythematosus. American Journal of Epidemiology 1994, 140, 632-642.

54. Cooper, G.S.; Dooley, M.A.; Treadwell, E.L.; St Clair, E.W.; Gilkeson, G.S. Risk factors for development of systemic lupus erythematosus: allergies, infections, and family history. Journal of Clinical Epidemiology 2002, 55, 982-989.

55. Ulff-Moller, C.J.; Nielsen, N.M.; Rostgaard, K.; Hjalgrim, H.; Frisch, M. Epstein-Barr virus-associated infectious mononucleosis and risk of systemic lupus erythematosus. Rheumatology 2010, 49, 1706-1712.

56. Pedersen, M.; Jacobsen, S.; Klarlund, M.; Pedersen, B.V.; Wiik, A.; Wohlfahrt, J.; Frisch, M. Environmental risk factors differ between rheumatoid arthritis with and without auto-antibodies against cyclic citrullinated peptides. Arthritis Research \& Therapy 2006, 8, doi: 10.1186/ar2022.

57. Tsokos, G.C.; Magrath, I.T.; Balow, J.E. Epstein-Barr virus induces normal B-cell responses but defective suppressor T-cell responses in patients with systemic lupus erythematosus. J. Immunol. 1983, 131, 1797-1801.

58. Berner, B.R.; Tary-Lehmann, M.; Yonkers, N.L.; Askari, A.D.; Lehmann, P.V.; Anthony, D.D., Phenotypic and functional analysis of EBV-specific memory CD8 cells in SLE. Cellular Immunology 2005, 235, 29-38.

59. Larsen, M.; Sauce, D.; Deback, C.; Arnaud, L.; Mathian, A.; Miyara, M.; Boutolleau, D.; Parizot, C.; Dorgham, K.; Papagno, L.; et al. Exhausted cytotoxic control of Epstein-Barr virus in human lupus. PLoS pathogens 2011, 7, e1002328. 
60. Kang, I.; Quan, T.; Nolasco, H.; Park, S.H.; Hong, M.S.; Crouch, J.; Pamer, E.G.; Howe, J.G.; Craft, J. Defective control of latent Epstein-Barr virus infection in systemic lupus erythematosus. J. Immunol. 2004, 172, 1287-1294.

61. Slaughter, L.; Carson, D.A.; Jensen, F.C.; Holbrook, T.L.; Vaughan, J.H. In vitro effects of Epstein-Barr virus on peripheral blood mononuclear cells from patients with rheumatoid arthritis and normal subjects. The Journal of Experimental Medicine 1978, 148, 1429-1434.

62. Tosato, G.; Steinberg, A.D.; Blaese, R.M. Defective EBV-specific suppressor T-cell function in rheumatoid arthritis. The New England Journal of Medicine 1981, 305, 1238-1243.

63. Toussirot, E.; Wendling, D.; Tiberghien, P.; Luka, J.; Roudier, J. Decreased T-cell precursor frequencies to Epstein-Barr virus glycoprotein Gp110 in peripheral blood correlate with disease activity and severity in patients with rheumatoid arthritis. Annals of the Rheumatic Diseases 2000, 59, 533-538.

64. Klatt, T.; Ouyang, Q.; Flad, T.; Koetter, I.; Buhring, H.J.; Kalbacher, H.; Pawelec, G.; Muller, C.A. Expansion of peripheral CD8+ CD28- T-cells in response to Epstein-Barr virus in patients with rheumatoid arthritis. The Journal of Rheumatology 2005, 32, 239-251.

65. Fraser, K.B.; Haire, M.; Millar, J.H.; McCrea, S. Increased tendency to spontaneous in vitro lymphocyte transformation in clinically active multiple sclerosis. Lancet 1979, 2, 175-176.

66. Craig, J.C.; Haire, M.; Merrett, J.D. T-cell-mediated suppression of Epstein-Barr virus-induced B lymphocyte activation in multiple sclerosis. Clinical Immunology and Immunopathology 1988, 48, 253-260.

67. Pender, M.P.; Csurhes, P.A.; Lenarczyk, A.; Pfluger, C.M.; Burrows, S.R. Decreased T-cell reactivity to Epstein-Barr virus infected lymphoblastoid cell lines in multiple sclerosis. Journal of Neurology, Neurosurgery, and Psychiatry 2009, 80, 498-505.

68. Hollsberg, P.; Hansen, H.J.; Haahr, S. Altered CD8+ T-cell responses to selected Epstein-Barr virus immunodominant epitopes in patients with multiple sclerosis. Clinical and Experimental Immunology 2003, 132, 137-143.

69. Jilek, S.; Schluep, M.; Meylan, P.; Vingerhoets, F.; Guignard, L.; Monney, A.; Kleeberg, J.; Le Goff, G.; Pantaleo, G.; Du Pasquier, R.A. Strong EBV-specific CD8+ T-cell response in patients with early multiple sclerosis. Brain: A Journal of Neurology 2008, 131, 1712-1721.

70. Lunemann, J.D.; Edwards, N.; Muraro, P.A.; Hayashi, S.; Cohen, J.I.; Munz, C.; Martin, R., Increased frequency and broadened specificity of latent EBV nuclear antigen-1-specific T-cells in multiple sclerosis. Brain: A Journal of Neurology 2006, 129, 1493-1506.

71. David-Ameline, J.; Lim, A.; Davodeau, F.; Peyrat, M.A.; Berthelot, J.M.; Semana, G.; Pannetier, C.; Gaschet, J.; Vie, H.; Even, J.; et al. Selection of T-cells reactive against autologous B lymphoblastoid cells during chronic rheumatoid arthritis. J. Immunol. 1996, 157, 4697-4706.

72. Scotet, E.; David-Ameline, J.; Peyrat, M.A.; Moreau-Aubry, A.; Pinczon, D.; Lim, A.; Even, J.; Semana, G.; Berthelot, J.M.; Breathnach, R.; et al. T-cell response to Epstein-Barr virus transactivators in chronic rheumatoid arthritis. The Journal of Experimental Medicine 1996, $184,1791-1800$. 
73. Scotet, E.; Peyrat, M.A.; Saulquin, X.; Retiere, C.; Couedel, C.; Davodeau, F.; Dulphy, N.; Toubert, A.; Bignon, J.D.; Lim, A.; et al. Frequent enrichment for CD8 T-cells reactive against common herpes viruses in chronic inflammatory lesions: towards a reassessment of the physiopathological significance of T-cell clonal expansions found in autoimmune inflammatory processes. European Journal of Immunology 1999, 29, 973-985.

74. Tan, L.C.; Mowat, A.G.; Fazou, C.; Rostron, T.; Roskell, H.; Dunbar, P.R.; Tournay, C.; Romagne, F.; Peyrat, M.A.; Houssaint, E.; et al., Specificity of T-cells in synovial fluid: high frequencies of CD8(+) T-cells that are specific for certain viral epitopes. Arthritis Research 2000, 2, 154-164.

75. Holmoy, T.; Vartdal, F. Cerebrospinal fluid T-cells from multiple sclerosis patients recognize autologous Epstein-Barr virus-transformed B-cells. Journal of Neurovirology 2004, 10, 52-56.

76. Holmoy, T.; Kvale, E.O.; Vartdal, F. Cerebrospinal fluid CD4+ T-cells from a multiple sclerosis patient cross-recognize Epstein-Barr virus and myelin basic protein. Journal of Neurovirology 2004, 10, 278-283.

77. Lossius, A.; Vartdal, F.; Holmoy, T. Vitamin D sensitive EBNA-1 specific T-cells in the cerebrospinal fluid of patients with multiple sclerosis. Journal of Neuroimmunology 2011, 240-241, 87-96.

78. Moon, U.Y.; Park, S.J.; Oh, S.T.; Kim, W.U.; Park, S.H.; Lee, S.H.; Cho, C.S.; Kim, H.Y.; Lee, W.K.; Lee, S.K. Patients with systemic lupus erythematosus have abnormally elevated Epstein-Barr virus load in blood. Arthritis Research \& Therapy 2004, 6, 295-302.

79. Yu, S.F.; Wu, H.C.; Tsai, W.C.; Yen, J.H.; Chiang, W.; Yuo, C.Y.; Lu, S.N.; Chiang, L.C.; Chen, C.J. Detecting Epstein-Barr virus DNA from peripheral blood mononuclear cells in adult patients with systemic lupus erythematosus in Taiwan. Medical Microbiology and Immunology 2005, 194, 115-120.

80. Gross, A.J.; Hochberg, D.; Rand, W.M.; Thorley-Lawson, D.A. EBV and systemic lupus erythematosus: a new perspective. J. Immunol. 2005, 174, 6599-6607.

81. Tosato, G.; Steinberg, A.D.; Yarchoan, R.; Heilman, C.A.; Pike, S.E.; De Seau, V.; Blaese, R.M., Abnormally elevated frequency of Epstein-Barr virus-infected B-cells in the blood of patients with rheumatoid arthritis. The Journal of Clinical Investigation 1984, 73, 1789-1795.

82. Blaschke, S.; Schwarz, G.; Moneke, D.; Binder, L.; Muller, G.; Reuss-Borst, M. Epstein-Barr virus infection in peripheral blood mononuclear cells, synovial fluid cells, and synovial membranes of patients with rheumatoid arthritis. The Journal of Rheumatology 2000, 27, 866-873.

83. Balandraud, N.; Meynard, J.B.; Auger, I.; Sovran, H.; Mugnier, B.; Reviron, D.; Roudier, J.; Roudier, C. Epstein-Barr virus load in the peripheral blood of patients with rheumatoid arthritis: accurate quantification using real-time polymerase chain reaction. Arthritis and Rheumatism 2003, 48, 1223-1228.

84. Balandraud, N.; Guis, S.; Meynard, J.B.; Auger, I.; Roudier, J.; Roudier, C. Long-term treatment with methotrexate or tumor necrosis factor alpha inhibitors does not increase epstein-barr virus load in patients with rheumatoid arthritis. Arthritis and Rheumatism 2007, 57, 762-767.

85. Lindsey, J.W.; Hatfield, L.M.; Crawford, M.P.; Patel, S. Quantitative PCR for Epstein-Barr virus DNA and RNA in multiple sclerosis. Mult. Scler. 2009, 15, 153-158. 
86. Lucas, R.M.; Ponsonby, A.L.; Dear, K.; Valery, P.; Pender, M.P.; Burrows, J.M.; Burrows, S.R.; Chapman, C.; Coulthard, A.; Dwyer, D.E.; et al. Current and past Epstein-Barr virus infection in risk of initial CNS demyelination. Neurology 2011, 77, 371-379.

87. Wagner, H.J.; Munger, K.L.; Ascherio, A. Plasma viral load of Epstein-Barr virus and risk of multiple sclerosis. European Journal of Neurology: The Official Journal of the European Federation of Neurological Societies 2004, 11, 833-834.

88. Alspaugh, M.A.; Shoji, H.; Nonoyama, M. A search for rheumatoid arthritis-associated nuclear antigen and Epstein-Barr virus specific antigens or genomes in tissues and cells from patients with rheumatoid arthritis. Arthritis and Rheumatism 1983, 26, 712-720.

89. Fox, R.I.; Chilton, T.; Rhodes, G.; Vaughan, J.H. Lack of reactivity of rheumatoid arthritis synovial membrane DNA with cloned Epstein Barr virus DNA probes. J. Immunol. 1986, 137, 498-501.

90. Brousset, P.; Caulier, M.; Cantagrel, A.; Dromer, C.; Mazieres, B.; Delsol, G. Absence of Epstein-Barr virus carrying cells in synovial membranes and subcutaneous nodules of patients with rheumatoid arthritis. Annals of the Rheumatic Diseases 1993, 52, 608-609.

91. Takei, M.; Mitamura, K.; Fujiwara, S.; Horie, T.; Ryu, J.; Osaka, S.; Yoshino, S.; Sawada, S. Detection of Epstein-Barr virus-encoded small RNA 1 and latent membrane protein 1 in synovial lining cells from rheumatoid arthritis patients. International Immunology 1997, 9, 739-743.

92. Takeda, T.; Mizugaki, Y.; Matsubara, L.; Imai, S.; Koike, T.; Takada, K. Lytic Epstein-Barr virus infection in the synovial tissue of patients with rheumatoid arthritis. Arthritis and Rheumatism 2000, 43, 1218-1225.

93. Niedobitek, G.; Lisner, R.; Swoboda, B.; Rooney, N.; Fassbender, H.G.; Kirchner, T.; Aigner, T.; Herbst, H. Lack of evidence for an involvement of Epstein-Barr virus infection of synovial membranes in the pathogenesis of rheumatoid arthritis. Arthritis and Rheumatism 2000, 43, 151-154.

94. Mehraein, Y.; Lennerz, C.; Ehlhardt, S.; Remberger, K.; Ojak, A.; Zang, K.D. Latent Epstein-Barr virus (EBV) infection and cytomegalovirus (CMV) infection in synovial tissue of autoimmune chronic arthritis determined by RNA- and DNA-in situ hybridization. Modern Pathology: An Official Journal of the US and Canadian Academy of Pathology Inc 2004, 17, 781-789.

95. Zhang, L.; Nikkari, S.; Skurnik, M.; Ziegler, T.; Luukkainen, R.; Mottonen, T.; Toivanen, P. Detection of herpesviruses by polymerase chain reaction in lymphocytes from patients with rheumatoid arthritis. Arthritis and Rheumatism 1993, 36, 1080-1086.

96. Mousavi-Jazi, M.; Bostrom, L.; Lovmark, C.; Linde, A.; Brytting, M.; Sundqvist, V.A. Infrequent detection of cytomegalovirus and Epstein-Barr virus DNA in synovial membrane of patients with rheumatoid arthritis. The Journal of Rheumatology 1998, 25, 623-628.

97. Saal, J.G.; Krimmel, M.; Steidle, M.; Gerneth, F.; Wagner, S.; Fritz, P.; Koch, S.; Zacher, J.; Sell, S.; Einsele, H.; et al. Synovial Epstein-Barr virus infection increases the risk of rheumatoid arthritis in individuals with the shared HLA-DR4 epitope. Arthritis and Rheumatism 1999, $42,1485-1496$. 
98. Hilton, D.A.; Love, S.; Fletcher, A.; Pringle, J.H. Absence of Epstein-Barr virus RNA in multiple sclerosis as assessed by in situ hybridisation. Journal of Neurology, Neurosurgery, and Psychiatry 1994, 57, 975-976.

99. Opsahl, M.L.; Kennedy, P.G. An attempt to investigate the presence of Epstein Barr virus in multiple sclerosis and normal control brain tissue. Journal of Neurology 2007, 254, 425-430.

100. Serafini, B.; Rosicarelli, B.; Franciotta, D.; Magliozzi, R.; Reynolds, R.; Cinque, P.; Andreoni, L.; Trivedi, P.; Salvetti, M.; Faggioni, A.; et al. Dysregulated Epstein-Barr virus infection in the multiple sclerosis brain. The Journal of Experimental Medicine 2007, 204, 2899-2912.

101. Willis, S.N.; Stadelmann, C.; Rodig, S.J.; Caron, T.; Gattenloehner, S.; Mallozzi, S.S.; Roughan, J.E.; Almendinger, S.E.; Blewett, M.M.; Bruck, W. et al. Epstein-Barr virus infection is not a characteristic feature of multiple sclerosis brain. Brain: A Journal of Neurology 2009, 132, 3318-3328.

102. Peferoen, L.A.; Lamers, F.; Lodder, L.N.; Gerritsen, W.H.; Huitinga, I.; Melief, J.; Giovannoni, G.; Meier, U.; Hintzen, R.Q.; Verjans, G.M. et al. Epstein Barr virus is not a characteristic feature in the central nervous system in established multiple sclerosis. Brain: A Journal of Neurology 2010, 133, e137.

103. Fatima, N.; Toscano, M.P.; Hunter, S.B.; Cohen, C. Controversial role of Epstein-Barr virus in multiple sclerosis. Applied Immunohistochemistry \& Molecular Morphology: AIMM / Official Publication of the Society for Applied Immunohistochemistry 2011, 19, 246-252.

104. Torkildsen, O.; Stansberg, C.; Angelskar, S.M.; Kooi, E.J.; Geurts, J.J.; van der Valk, P.; Myhr, K.M.; Steen, V.M.; Bo, L. Upregulation of immunoglobulin-related genes in cortical sections from multiple sclerosis patients. Brain Pathol. 2010, 20, 720-729.

105. Sargsyan, S.A.; Shearer, A.J.; Ritchie, A.M.; Burgoon, M.P.; Anderson, S.; Hemmer, B.; Stadelmann, C.; Gattenlohner, S.; Owens, G.P.; Gilden, D.; et al. Absence of Epstein-Barr virus in the brain and CSF of patients with multiple sclerosis. Neurology 2010, 74, 1127-1135.

106. Lassmann, H.; Niedobitek, G.; Aloisi, F.; Middeldorp, J.M. Epstein-Barr virus in the multiple sclerosis brain: a controversial issue-report on a focused workshop held in the Centre for Brain Research of the Medical University of Vienna, Austria. Brain: A Journal of Neurology 2011, 134, 2772-2786.

107. Tzartos, J.S.; Khan, G.; Vossenkamper, A.; Cruz-Sadaba, M.; Lonardi, S.; Sefia, E.; Meager, A.; Elia, A.; Middeldorp, J.M.; Clemens, M. et al. Association of innate immune activation with latent Epstein-Barr virus in active MS lesions. Neurology 2012, 78, 15-23.

108. Thorley-Lawson, D.A.; Gross, A. Persistence of the Epstein-Barr virus and the origins of associated lymphomas. The New England Journal of Medicine 2004, 350, 1328-1337.

109. Tsurumi, T.; Fujita, M.; Kudoh, A. Latent and lytic Epstein-Barr virus replication strategies. Reviews in Medical Virology 2005, 15, 3-15.

110. He, B.; Raab-Traub, N.; Casali, P.; Cerutti, A. EBV-encoded latent membrane protein 1 cooperates with BAFF/BLyS and APRIL to induce T-cell-independent Ig heavy chain class switching. J. Immunol. 2003, 171, 5215-5224.

111. Graham, J.P.; Arcipowski, K.M.; Bishop, G.A. Differential B-lymphocyte regulation by CD40 and its viral mimic, latent membrane protein 1. Immunological Reviews 2010, 237, 226-248. 
112. Mancao, C.; Hammerschmidt, W. Epstein-Barr virus latent membrane protein $2 \mathrm{~A}$ is a B-cell receptor mimic and essential for B-cell survival. Blood 2007, 110, 3715-3721.

113. Pender, M.P. Infection of autoreactive B lymphocytes with EBV, causing chronic autoimmune diseases. Trends in Immunology 2003, 24, 584-588.

114. Pender, M.P. CD8+ T-Cell Deficiency, Epstein-Barr Virus Infection, Vitamin D Deficiency, and Steps to Autoimmunity: A Unifying Hypothesis. Autoimmune Diseases 2012, doi: 10.1155/2012/189096.

115. Swanson-Mungerson, M.A.; Caldwell, R.G.; Bultema, R.; Longnecker, R. Epstein-Barr virus LMP2A alters in vivo and in vitro models of B-cell anergy, but not deletion, in response to autoantigen. Journal of Virology 2005, 79, 7355-7362.

116. Wang, H.; Nicholas, M.W.; Conway, K.L.; Sen, P.; Diz, R.; Tisch, R.M.; Clarke, S.H. EBV latent membrane protein $2 \mathrm{~A}$ induces autoreactive B-cell activation and TLR hypersensitivity. J. Immunol. 2006, 177, 2793-2802.

117. Roughan, J.E.; Thorley-Lawson, D.A. The intersection of Epstein-Barr virus with the germinal center. Journal of Virology 2009, 83, 3968-3976.

118. Tracy, S.I.; Kakalacheva, K.; Lunemann, J.D.; Luzuriaga, K.; Middeldorp, J.; Thorley-Lawson, D.A. Persistence of epstein-barr virus in self-reactive memory B-cells. Journal of Virology 2012, 86, 12330-12340.

119. Tokunaga, M.; Uemura, Y.; Tokudome, T.; Sato, E. Epstein-Barr virus-infected T-cells in infectious mononucleosis. Acta Pathologica Japonica 1993, 43, 146-147.

120. Anagnostopoulos, I.; Hummel, M.; Kreschel, C.; Stein, H. Morphology, immunophenotype, and distribution of latently and/or productively Epstein-Barr virus-infected cells in acute infectious mononucleosis: implications for the interindividual infection route of Epstein-Barr virus. Blood 1995, 85, 744-750.

121. Kimura, H.; Hoshino, Y.; Kanegane, H.; Tsuge, I.; Okamura, T.; Kawa, K.; Morishima, T. Clinical and virologic characteristics of chronic active Epstein-Barr virus infection. Blood 2001, 98, 280-286.

122. Dreyfus, D.H.; Nagasawa, M.; Pratt, J.C.; Kelleher, C.A.; Gelfand, E.W. Inactivation of NF-kappaB by EBV BZLF-1-encoded ZEBRA protein in human T-cells. J. Immunol. 1999, 163, 6261-6268.

123. Dreyfus, D.H.; Nagasawa, M.; Kelleher, C.A.; Gelfand, E.W. Stable expression of Epstein-Barr virus BZLF-1-encoded ZEBRA protein activates p53-dependent transcription in human Jurkat T-lymphoblastoid cells. Blood 2000, 96, 625-634.

124. Menet, A.; Speth, C.; Larcher, C.; Prodinger, W.M.; Schwendinger, M.G.; Chan, P.; Jager, M.; Schwarzmann, F.; Recheis, H.; Fontaine, M.; et al. Epstein-Barr virus infection of human astrocyte cell lines. Journal of Virology 1999, 73, 7722-7733.

125. Casiraghi, C.; Dorovini-Zis, K.; Horwitz, M.S. Epstein-Barr virus infection of human brain microvessel endothelial cells: a novel role in multiple sclerosis. Journal of Neuroimmunology 2011, 230, 173-177.

126. Posnett, D.N. Herpesviruses and autoimmunity. Curr. Opin. Investig. Drugs 2008, 9, 505-514. 
127. Xu, D.; Brumm, K.; Zhang, L. The latent membrane protein 1 of Epstein-Barr virus (EBV) primes EBV latency cells for type I interferon production. The Journal of Biological Chemistry 2006, 281, 9163-9169.

128. Busch, L.K.; Bishop, G.A. The EBV transforming protein, latent membrane protein 1, mimics and cooperates with CD40 signaling in B lymphocytes. J. Immunol. 1999, 162, 2555-2561.

129. Burdin, N.; Peronne, C.; Banchereau, J.; Rousset, F. Epstein-Barr virus transformation induces B lymphocytes to produce human interleukin 10. The Journal of Experimental Medicine 1993, 177, 295-304.

130. Karageorgas, T.P.; Tseronis, D.D.; Mavragani, C.P. Activation of type I interferon pathway in systemic lupus erythematosus: Association with distinct clinical phenotypes. Journal of Biomedicine \& Biotechnology 2011, doi: 10.1155/2011/273907.

131. Baccala, R.; Hoebe, K.; Kono, D.H.; Beutler, B.; Theofilopoulos, A.N. TLR-dependent and TLRindependent pathways of type I interferon induction in systemic autoimmunity. Nature Medicine 2007, 13, 543-551.

132. Quan, T.E.; Roman, R.M.; Rudenga, B.J.; Holers, V.M.; Craft, J.E. Epstein-Barr virus promotes interferon-alpha production by plasmacytoid dendritic cells. Arthritis and Rheumatism 2010, 62, 1693-1701.

133. Valente, R.M.; Ehlers, E.; Xu, D.; Ahmad, H.; Steadman, A.; Blasnitz, L.; Zhou, Y.; Kastanek, L.; Meng, B.; Zhang, L. Toll-like receptor 7 stimulates the expression of epstein-barr virus latent membrane protein 1. PloS one 2012, 7, e43317.

134. Serafini, B.; Severa, M.; Columba-Cabezas, S.; Rosicarelli, B.; Veroni, C.; Chiappetta, G.; Magliozzi, R.; Reynolds, R.; Coccia, E.M.; Aloisi, F. Epstein-Barr virus latent infection and BAFF expression in B-cells in the multiple sclerosis brain: implications for viral persistence and intrathecal B-cell activation. Journal of Neuropathology and Experimental Neurology 2010, 69, 677-693.

135. Salamon, D.; Adori, M.; Ujvari, D.; Wu, L.; Kis, L.L.; Madapura, H.S.; Nagy, N.; Klein, G.; Klein, E. Latency type-dependent modulation of Epstein-Barr virus-encoded latent membrane protein 1 expression by type I interferons in B-cells. Journal of Virology 2012, 86, 4701-4707.

136. Kis, L.L.; Takahara, M.; Nagy, N.; Klein, G.; Klein, E. IL-10 can induce the expression of EBV-encoded latent membrane protein-1 (LMP-1) in the absence of EBNA-2 in B lymphocytes and in Burkitt lymphoma- and NK lymphoma-derived cell lines. Blood 2006, 107, 2928-2935.

137. Konforte, D.; Simard, N.; Paige, C.J. Interleukin-21 regulates expression of key Epstein-Barr virus oncoproteins, EBNA2 and LMP1, in infected human B-cells. Virology 2008, 374, 100-113.

138. Hulshof, S.; Montagne, L.; De Groot, C.J.; Van Der Valk, P. Cellular localization and expression patterns of interleukin-10, interleukin-4, and their receptors in multiple sclerosis lesions. Glia 2002, 38, 24-35.

139. Tzartos, J.S.; Craner, M.J.; Friese, M.A.; Jakobsen, K.B.; Newcombe, J.; Esiri, M.M.; Fugger, L. IL-21 and IL-21 receptor expression in lymphocytes and neurons in multiple sclerosis brain. The American Journal of Pathology 2011, 178, 794-802.

140. Cush, J.J.; Splawski, J.B.; Thomas, R.; McFarlin, J.E.; Schulze-Koops, H.; Davis, L.S.; Fujita, K.; Lipsky, P.E. Elevated interleukin-10 levels in patients with rheumatoid arthritis. Arthritis and Rheumatism 1995, 38, 96-104. 
141. Alanara, T.; Karstila, K.; Moilanen, T.; Silvennoinen, O.; Isomaki, P. Expression of IL-10 family cytokines in rheumatoid arthritis: elevated levels of IL-19 in the joints. Scandinavian Journal of Rheumatology 2010, 39, 118-126.

142. Conigliaro, P.; Perricone, C.; Benson, R.A.; Garside, P.; Brewer, J.M.; Perricone, R.; Valesini, G. The type I IFN system in rheumatoid arthritis. Autoimmunity 2010, 43, 220-225.

143. Moura, R.A.; Cascao, R.; Perpetuo, I.; Canhao, H.; Vieira-Sousa, E.; Mourao, A.F.; Rodrigues, A.M.; Polido-Pereira, J.; Queiroz, M.V.; Rosario, H.S.; et al. Cytokine pattern in very early rheumatoid arthritis favours B-cell activation and survival. Rheumatology (Oxford) 2011, 50, 278-282.

144. Grondal, G.; Gunnarsson, I.; Ronnelid, J.; Rogberg, S.; Klareskog, L.; Lundberg, I. Cytokine production, serum levels and disease activity in systemic lupus erythematosus. Clinical and Experimental Rheumatology 2000, 18, 565-570.

145. Dolff, S.; Abdulahad, W.H.; Westra, J.; Doornbos-van der Meer, B.; Limburg, P.C.; Kallenberg, C.G.; Bijl, M. Increase in IL-21 producing T-cells in patients with systemic lupus erythematosus. Arthritis Research \& Therapy 2011, 13, 157.

146. Daibata, M.; Speck, S.H.; Mulder, C.; Sairenji, T. Regulation of the BZLF1 promoter of Epstein-Barr virus by second messengers in anti-immunoglobulin-treated B-cells. Virology 1994, 198, 446-454.

147. Laichalk, L.L.; Thorley-Lawson, D.A. Terminal differentiation into plasma cells initiates the replicative cycle of Epstein-Barr virus in vivo. Journal of Virology 2005, 79, 1296-1307.

148. Souto-Carneiro, M.M.; Mahadevan, V.; Takada, K.; Fritsch-Stork, R.; Nanki, T.; Brown, M.; Fleisher, T.A.; Wilson, M.; Goldbach-Mansky, R.; Lipsky, P.E. Alterations in peripheral blood memory B-cells in patients with active rheumatoid arthritis are dependent on the action of tumour necrosis factor. Arthritis Research \& Therapy 2009, 11, 84.

149. Corcione, A.; Casazza, S.; Ferretti, E.; Giunti, D.; Zappia, E.; Pistorio, A.; Gambini, C.; Mancardi, G.L.; Uccelli, A.; Pistoia, V. Recapitulation of B-cell differentiation in the central nervous system of patients with multiple sclerosis. Proceedings of the National Academy of Sciences of the United States of America 2004, 101, 11064-11069.

150. Lee-Chang, C.; Top, I.; Zephir, H.; Dubucquoi, S.; Trauet, J.; Dussart, P.; Prin, L.; Vermersch, P. Primed status of transitional B-cells associated with their presence in the cerebrospinal fluid in early phases of multiple sclerosis. Clin. Immunol. 2011, 139, 12-20.

151. Prineas, J.W. Multiple sclerosis: presence of lymphatic capillaries and lymphoid tissue in the brain and spinal cord. Science 1979, 203, 1123-1125.

152. Serafini, B.; Rosicarelli, B.; Magliozzi, R.; Stigliano, E.; Aloisi, F. Detection of ectopic B-cell follicles with germinal centers in the meninges of patients with secondary progressive multiple sclerosis. Brain Pathol. 2004, 14, 164-174.

153. Perl, A.; Fernandez, D.; Telarico, T.; Phillips, P.E. Endogenous retroviral pathogenesis in lupus. Current Opinion in Rheumatology 2010, 22, 483-492.

154. Sutkowski, N.; Conrad, B.; Thorley-Lawson, D.A.; Huber, B.T. Epstein-Barr virus transactivates the human endogenous retrovirus HERV-K18 that encodes a superantigen. Immunity 2001, 15, 579-589. 
155. Sicat, J.; Sutkowski, N.; Huber, B.T. Expression of human endogenous retrovirus HERV-K18 superantigen is elevated in juvenile rheumatoid arthritis. The Journal of Rheumatology 2005, $32,1821-1831$.

156. Tai, A.K.; O'Reilly, E.J.; Alroy, K.A.; Simon, K.C.; Munger, K.L.; Huber, B.T.; Ascherio, A. Human endogenous retrovirus-K18 Env as a risk factor in multiple sclerosis. Mult. Scler. 2008, $14,1175-1180$.

157. Virtanen, J.O.; Jacobson, S. Viruses and multiple sclerosis. CNS \& Neurological Disorders Drug Targets 2012, 11, 528-544.

158. Junker, A.; Ivanidze, J.; Malotka, J.; Eiglmeier, I.; Lassmann, H.; Wekerle, H.; Meinl, E.; Hohlfeld, R.; Dornmair, K. Multiple sclerosis: T-cell receptor expression in distinct brain regions. Brain: A Journal of Neurology 2007, 130, 2789-2799.

159. Kurokawa, M.; Kato, T.; Masuko-Hongo, K.; Ueda, S.; Kobata, T.; Okubo, M.; Nishimaki, T.; Akaza, T.; Yoshino, S.; Kasukawa, R.; et al. Characterisation of T-cell clonotypes that accumulated in multiple joints of patients with rheumatoid arthritis. Annals of the Rheumatic Diseases 1999, 58, 546-553.

160. Cantaert, T.; Brouard, S.; Thurlings, R.M.; Pallier, A.; Salinas, G.F.; Braud, C.; Klarenbeek, P.L.; de Vries, N.; Zhang, Y.; Soulillou, J.P.; et al. Alterations of the synovial T-cell repertoire in anti-citrullinated protein antibody-positive rheumatoid arthritis. Arthritis and Rheumatism 2009, 60, 1944-1956.

161. Mameli, G.; Poddighe, L.; Mei, A.; Uleri, E.; Sotgiu, S.; Serra, C.; Manetti, R.; Dolei, A. Expression and activation by epstein barr virus of human endogenous retroviruses-w in blood cells and astrocytes: Inference for multiple sclerosis. PloS one 2012, 7, e44991.

162. Perron, H.; Lalande, B.; Gratacap, B.; Laurent, A.; Genoulaz, O.; Geny, C.; Mallaret, M.; Schuller, E.; Stoebner, P.; Seigneurin, J.M. Isolation of retrovirus from patients with multiple sclerosis. Lancet 1991, 337, 862-863.

163. Garson, J.A.; Tuke, P.W.; Giraud, P.; Paranhos-Baccala, G.; Perron, H. Detection of virion-associated MSRV-RNA in serum of patients with multiple sclerosis. Lancet 1998, 351, 33.

164. Dolei, A.; Serra, C.; Mameli, G.; Pugliatti, M.; Sechi, G.; Cirotto, M.C.; Rosati, G.; Sotgiu, S. Multiple sclerosis-associated retrovirus (MSRV) in Sardinian MS patients. Neurology 2002, $58,471-473$.

165. Perron, H.; Jouvin-Marche, E.; Michel, M.; Ounanian-Paraz, A.; Camelo, S.; Dumon, A.; Jolivet-Reynaud, C.; Marcel, F.; Souillet, Y.; Borel, E. et al. Multiple sclerosis retrovirus particles and recombinant envelope trigger an abnormal immune response in vitro, by inducing polyclonal Vbeta16 T-lymphocyte activation. Virology 2001, 287, 321-332.

166. Serra, C.; Mameli, G.; Arru, G.; Sotgiu, S.; Rosati, G.; Dolei, A. In vitro modulation of the multiple sclerosis (MS)-associated retrovirus by cytokines: implications for MS pathogenesis. Journal of Neurovirology 2003, 9, 637-643.

167. Rolland, A.; Jouvin-Marche, E.; Saresella, M.; Ferrante, P.; Cavaretta, R.; Creange, A.; Marche, P.; Perron, H., Correlation between disease severity and in vitro cytokine production mediated by MSRV (multiple sclerosis associated retroviral element) envelope protein in patients with multiple sclerosis. Journal of Neuroimmunology 2005, 160, 195-203. 
168. Saresella, M.; Rolland, A.; Marventano, I.; Cavarretta, R.; Caputo, D.; Marche, P.; Perron, H.; Clerici, M. Multiple sclerosis-associated retroviral agent (MSRV)-stimulated cytokine production in patients with relapsing-remitting multiple sclerosis. Mult. Scler. 2009, 15, 443-447.

169. Fujinami, R.S.; Oldstone, M.B.; Wroblewska, Z.; Frankel, M.E.; Koprowski, H. Molecular mimicry in virus infection: crossreaction of measles virus phosphoprotein or of herpes simplex virus protein with human intermediate filaments. Proceedings of the National Academy of Sciences of the United States of America 1983, 80, 2346-2350.

170. Wucherpfennig, K.W.; Strominger, J.L. Molecular mimicry in T-cell-mediated autoimmunity: Viral peptides activate human T-cell clones specific for myelin basic protein. Cell 1995, $80,695-705$.

171. Gross, D.M.; Forsthuber, T.; Tary-Lehmann, M.; Etling, C.; Ito, K.; Nagy, Z.A.; Field, J.A.; Steere, A.C.; Huber, B.T. Identification of LFA-1 as a candidate autoantigen in treatment-resistant Lyme arthritis. Science 1998, 281, 703-706.

172. Munz, C.; Lunemann, J.D.; Getts, M.T.; Miller, S.D. Antiviral immune responses: Triggers of or triggered by autoimmunity? Nature reviews. Immunology 2009, 9, 246-258.

173. James, J.A.; Harley, J.B. Linear epitope mapping of an Sm B/B' polypeptide. J. Immunol. 1992, 148, 2074-2079.

174. Sabbatini, A.; Bombardieri, S.; Migliorini, P. Autoantibodies from patients with systemic lupus erythematosus bind a shared sequence of $\mathrm{SmD}$ and Epstein-Barr virus-encoded nuclear antigen EBNA I. European Journal of Immunology 1993, 23, 1146-1152.

175. James, J.A.; Scofield, R.H.; Harley, J.B. Lupus humoral autoimmunity after short peptide immunization. Annals of the New York Academy of Sciences 1997, 815, 124-127.

176. Sundar, K.; Jacques, S.; Gottlieb, P.; Villars, R.; Benito, M.E.; Taylor, D.K.; Spatz, L.A. Expression of the Epstein-Barr virus nuclear antigen-1 (EBNA-1) in the mouse can elicit the production of anti-dsDNA and anti-Sm antibodies. Journal of Autoimmunity 2004, 23, 127-140.

177. McClain, M.T.; Heinlen, L.D.; Dennis, G.J.; Roebuck, J.; Harley, J.B.; James, J.A. Early events in lupus humoral autoimmunity suggest initiation through molecular mimicry. Nature Medicine 2005, 11, 85-89.

178. Vossenaar, E.R.; Zendman, A.J.; van Venrooij, W.J.; Pruijn, G.J. PAD A growing family of citrullinating enzymes: genes, features and involvement in disease. BioEssays: News and Reviews in Molecular, Cellular and Developmental Biology 2003, 25, 1106-1118.

179. Pratesi, F.; Tommasi, C.; Anzilotti, C.; Chimenti, D.; Migliorini, P. Deiminated Epstein-Barr virus nuclear antigen 1 is a target of anti-citrullinated protein antibodies in rheumatoid arthritis. Arthritis and Rheumatism 2006, 54, 733-741.

180. Bax, M.; van Heemst, J.; Huizinga, T.W.; Toes, R.E. Genetics of rheumatoid arthritis: What have we learned? Immunogenetics 2011, 63, 459-466.

181. Roudier, J.; Petersen, J.; Rhodes, G.H.; Luka, J.; Carson, D.A. Susceptibility to rheumatoid arthritis maps to a T-cell epitope shared by the HLA-Dw4 DR beta-1 chain and the Epstein-Barr virus glycoprotein gp110. Proceedings of the National Academy of Sciences of the United States of America 1989, 86, 5104-5108.

182. La Cava, A.; Nelson, J.L.; Ollier, W.E.; MacGregor, A.; Keystone, E.C.; Thorne, J.C.; Scavulli, J.F.; Berry, C.C.; Carson, D.A.; Albani, S. Genetic bias in immune responses to a 
cassette shared by different microorganisms in patients with rheumatoid arthritis. The Journal of Clinical Investigation 1997, 100, 658-663.

183. Lang, H.L.; Jacobsen, H.; Ikemizu, S.; Andersson, C.; Harlos, K.; Madsen, L.; Hjorth, P.; Sondergaard, L.; Svejgaard, A.; Wucherpfennig, K.; et al. A functional and structural basis for TCR cross-reactivity in multiple sclerosis. Nature Immunology 2002, 3, 940-943.

184. Gregersen, J.W.; Kranc, K.R.; Ke, X.; Svendsen, P.; Madsen, L.S.; Thomsen, A.R.; Cardon, L.R.; Bell, J.I.; Fugger, L. Functional epistasis on a common MHC haplotype associated with multiple sclerosis. Nature 2006, 443, 574-577.

185. Lunemann, J.D.; Jelcic, I.; Roberts, S.; Lutterotti, A.; Tackenberg, B.; Martin, R.; Munz, C. EBNA1-specific T-cells from patients with multiple sclerosis cross react with myelin antigens and co-produce IFN-gamma and IL-2. The Journal of Experimental Medicine 2008, 205, 1763-1773.

186. van Noort, J.M.; van Sechel, A.C.; Bajramovic, J.J.; el Ouagmiri, M.; Polman, C.H.; Lassmann, H.; Ravid, R. The small heat-shock protein alpha B-crystallin as candidate autoantigen in multiple sclerosis. Nature 1995, 375, 798-801.

187. van Sechel, A.C.; Bajramovic, J.J.; van Stipdonk, M.J.; Persoon-Deen, C.; Geutskens, S.B.; van Noort, J.M. EBV-induced expression and HLA-DR-restricted presentation by human B-cells of alpha B-crystallin, a candidate autoantigen in multiple sclerosis. J. Immunol. 1999, $162,129-135$.

188. van Noort, J.M.; Bajramovic, J.J.; Plomp, A.C.; van Stipdonk, M.J. Mistaken self, a novel model that links microbial infections with myelin-directed autoimmunity in multiple sclerosis. Journal of Neuroimmunology 2000, 105, 46-57.

189. Ousman, S.S.; Tomooka, B.H.; van Noort, J.M.; Wawrousek, E.F.; O'Connor, K.C.; Hafler, D.A.; Sobel, R.A.; Robinson, W.H.; Steinman, L., Protective and therapeutic role for alphaB-crystallin in autoimmune demyelination. Nature 2007, 448, 474-479.

190. Rand, K.H.; Houck, H.; Denslow, N.D.; Heilman, K.M. Molecular approach to find target(s) for oligoclonal bands in multiple sclerosis. Journal of Neurology, Neurosurgery, and Psychiatry 1998, 5, 48-55.

191. Wucherpfennig, K.W. Mechanisms for the induction of autoimmunity by infectious agents. The Journal of Clinical Investigation 2001, 108, 1097-1104.

192. Sospedra, M.; Martin, R. Immunology of multiple sclerosis. Annual Review of Immunology 2005, 23, 683-747.

193. Libbey, J.E.; Fujinami, R.S. Potential triggers of MS. Results and Problems in Cell Differentiation 2010, 51, 21-42.

194. Lehmann, P.V.; Forsthuber, T.; Miller, A.; Sercarz, E.E. Spreading of T-cell autoimmunity to cryptic determinants of an autoantigen. Nature 1992, 358, 155-157.

195. Miller, S.D.; Vanderlugt, C.L.; Begolka, W.S.; Pao, W.; Yauch, R.L.; Neville, K.L.; Katz-Levy, Y.; Carrizosa, A.; Kim, B.S. Persistent infection with Theiler's virus leads to CNS autoimmunity via epitope spreading. Nature Medicine 1997, 3, 1133-1136.

196. Odumade, O.A.; Knight, J.A.; Schmeling, D.O.; Masopust, D.; Balfour, H.H., Jr.; Hogquist, K.A. Primary Epstein-Barr virus infection does not erode preexisting CD8(+) T-cell memory in humans. The Journal of Experimental Medicine 2012, 209, 471-478. 
197. Bar-Or, A.; Fawaz, L.; Fan, B.; Darlington, P.J.; Rieger, A.; Ghorayeb, C.; Calabresi, P.A.; Waubant, E.; Hauser, S.L.; Zhang, J.; et al. Abnormal B-cell cytokine responses a trigger of T-cell-mediated disease in MS? Annals of Neurology 2010, 67, 452-461.

198. Cusick, M.F.; Libbey, J.E.; Fujinami, R.S. Molecular mimicry as a mechanism of autoimmune disease. Clinical Reviews in Allergy \& Immunology 2012, 42, 102-111.

199. Ji, Q.; Perchellet, A.; Goverman, J.M. Viral infection triggers central nervous system autoimmunity via activation of CD8+ T-cells expressing dual TCRs. Nature Immunology 2010, $11,628-634$.

200. Bernasconi, N.L.; Traggiai, E.; Lanzavecchia, A. Maintenance of serological memory by polyclonal activation of human memory B-cells. Science 2002, 298, 2199-2202.

201. Desai-Mehta, A.; Lu, L.; Ramsey-Goldman, R.; Datta, S.K. Hyperexpression of CD40 ligand by $\mathrm{B}$ and T-cells in human lupus and its role in pathogenic autoantibody production. The Journal of Clinical Investigation 1996, 97, 2063-2073.

202. Huang, W.X.; Huang, P.; Hillert, J. Systemic upregulation of CD40 and CD40 ligand mRNA expression in multiple sclerosis. Mult. Scler. 2000, 6, 61-65.

203. Sofo, V.; Salmeri, F.M.; Di Bella, P.; Sessa, E.; D'Aleo, G.; Trimarchi, G.; Bramanti, P. Short communication: Impairment of membrane markers on peripheral blood mononuclear cells and imbalance of cytokine secretion in the pathogenesis of multiple sclerosis active phases. Journal of Interferon \& Cytokine Research: The Official Journal of the International Society for Interferon and Cytokine Research 2005, 25, 661-665.

204. Komatsuda, A.; Wakui, H.; Iwamoto, K.; Ozawa, M.; Togashi, M.; Masai, R.; Maki, N.; Hatakeyama, T.; Sawada, K. Up-regulated expression of Toll-like receptors mRNAs in peripheral blood mononuclear cells from patients with systemic lupus erythematosus. Clinical and Experimental Immunology 2008, 152, 482-487.

205. Alaaeddine, N.; Hassan, G.S.; Yacoub, D.; Mourad, W. CD154: An immunoinflammatory mediator in systemic lupus erythematosus and rheumatoid arthritis. Clinical \& Developmental Immunology 2012, doi: 10.1155/2012/490148.

206. Chamberlain, N.D.; Kim, S.J.; Vila, O.M.; Volin, M.V.; Volkov, S.; Pope, R.M.; Arami, S.; Mandelin, A.M., 2nd; Shahrara, S. Ligation of TLR7 by rheumatoid arthritis synovial fluid single strand RNA induces transcription of TNFalpha in monocytes. Annals of the Rheumatic Diseases 2012, doi: 10.1136/annrheumdis-2011-201203.

207. Vandvik, B.; Norrby, E. Oligoclonal IgG antibody response in the central nervous system to different measles virus antigens in subacute sclerosing panencephalitis. Proceedings of the National Academy of Sciences of the United States of America 1973, 70, 1060-1063.

208. Vartdal, F.; Vandvik, B.; Michaelsen, T.E.; Loe, K.; Norrby, E. Neurosyphilis: Intrathecal synthesis of oligoclonal antibodies to Treponema pallidum. Annals of Neurology 1982, $11,35-40$.

209. Vartdal, F.; Vandvik, B.; Norrby, E. Viral and bacterial antibody responses in multiple sclerosis. Annals of Neurology 1980, 8, 248-255.

210. Vartdal, F.; Vandvik, B. Multiple sclerosis. Electrofocused "bands" of oligoclonal CSF IgG do not carry antibody activity against measles, varicella-zoster or rotaviruses. Journal of the Neurological Sciences 1982, 54, 99-107. 
211. Owens, G.P.; Ritchie, A.M.; Gilden, D.H.; Burgoon, M.P.; Becker, D.; Bennett, J.L. Measles virus-specific plasma cells are prominent in subacute sclerosing panencephalitis CSF. Neurology 2007, 68, 1815-1819.

212. Ahlgren, C.; Oden, A.; Bergstrom, T.; Lycke, J. Serum and CSF measles antibody levels increase over time in patients with multiple sclerosis or clinically isolated syndrome. Journal of Neuroimmunology 2012, 247, 70-74.

213. Sundstrom, P.; Juto, P.; Wadell, G.; Hallmans, G.; Svenningsson, A.; Nystrom, L.; Dillner, J.; Forsgren, L. An altered immune response to Epstein-Barr virus in multiple sclerosis: A prospective study. Neurology 2004, 62, 2277-2282.

214. Sellner, J.; Cepok, S.; Kalluri, S.R.; Nestler, A.; Kleiter, I.; Kumpfel, T.; Linker, R.; Melms, A.; Menge, T.; Tumani, H.; et al. Aquaporin 4 antibody positive central nervous system autoimmunity and multiple sclerosis are characterized by a distinct profile of antibodies to herpes viruses. Neurochemistry International 2010, 57, 662-667.

215. Hogan, L.H.; Co, D.O.; Karman, J.; Heninger, E.; Suresh, M.; Sandor, M. Virally activated CD8 T-cells home to Mycobacterium bovis BCG-induced granulomas but enhance antimycobacterial protection only in immunodeficient mice. Infection and Immunity 2007, 75, 1154-1166.

216. Vossenkamper, A.; Lutalo, P.M.; Spencer, J. Translational Mini-Review Series on B-cell subsets in disease. Transitional B-cells in systemic lupus erythematosus and Sjogren's syndrome: Clinical implications and effects of B-cell-targeted therapies. Clinical and Experimental Immunology 2012, 167, 7-14.

217. Marston, B.; Palanichamy, A.; Anolik, J.H. B-cells in the pathogenesis and treatment of rheumatoid arthritis. Current Opinion in Rheumatology 2010, 22, 307-315.

218. Meier, U.C.; Giovannoni, G.; Tzartos, J.S.; Khan, G. Translational Mini-Review Series on B-cell subsets in disease. B-cells in multiple sclerosis: drivers of disease pathogenesis and Trojan horse for Epstein-Barr virus entry to the central nervous system? Clinical and Experimental Immunology 2012, 167, 1-6.

219. Babcock, G.J.; Decker, L.L.; Volk, M.; Thorley-Lawson, D.A. EBV persistence in memory B-cells in vivo. Immunity 1998, 9, 395-404.

220. Yajima, M.; Imadome, K.; Nakagawa, A.; Watanabe, S.; Terashima, K.; Nakamura, H.; Ito, M.; Shimizu, N.; Honda, M.; Yamamoto, N.; et al. A new humanized mouse model of Epstein-Barr virus infection that reproduces persistent infection, lymphoproliferative disorder, and cell-mediated and humoral immune responses. The Journal of Infectious Diseases 2008, 198, 673-682.

221. Ma, S.D.; Hegde, S.; Young, K.H.; Sullivan, R.; Rajesh, D.; Zhou, Y.; Jankowska-Gan, E.; Burlingham, W.J.; Sun, X.; Gulley, M.L.; et al. A new model of Epstein-Barr virus infection reveals an important role for early lytic viral protein expression in the development of lymphomas. Journal of Virology 2011, 85, 165-177.

222. Kuwana, Y.; Takei, M.; Yajima, M.; Imadome, K.; Inomata, H.; Shiozaki, M.; Ikumi, N.; Nozaki, T.; Shiraiwa, H.; Kitamura, N.; et al. Epstein-Barr virus induces erosive arthritis in humanized mice. PloS one 2011, 6, e26630. 
223. Greenblatt, M.B.; Vbranac, V.; Tivey, T.; Tsang, K.; Tager, A.M.; Aliprantis, A.O. Graft versus host disease in the bone marrow, liver and thymus humanized mouse model. PloS one 2012, 7, e44664.

224. Cohen, J.I.; Fauci, A.S.; Varmus, H.; Nabel, G.J. Epstein-Barr virus: an important vaccine target for cancer prevention. Science Translational Medicine 2011, 3, $107 \mathrm{fs} 7$.

225. Sokal, E.M.; Hoppenbrouwers, K.; Vandermeulen, C.; Moutschen, M.; Leonard, P.; Moreels, A.; Haumont, M.; Bollen, A.; Smets, F.; Denis, M. Recombinant gp350 vaccine for infectious mononucleosis: a phase 2, randomized, double-blind, placebo-controlled trial to evaluate the safety, immunogenicity, and efficacy of an Epstein-Barr virus vaccine in healthy young adults. The Journal of Infectious Diseases 2007, 196, 1749-1753.

(C) 2012 by the authors; licensee MDPI, Basel, Switzerland. This article is an open access article distributed under the terms and conditions of the Creative Commons Attribution license (http://creativecommons.org/licenses/by/3.0/). 